GEOHYDROLOGY OF ROCKS PENETRATED BY TEST WELL USW H-6, YUCCA MOUNTAIN, NYE COUNTY, NEVADA

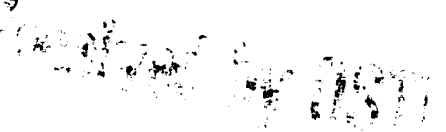

U.S. GEOLOGICAL SURVEY

Water-Resources Investigations Report 89-4025

Prepared in cooperation with the

U.S. DEPARTMENT OF ENERGY

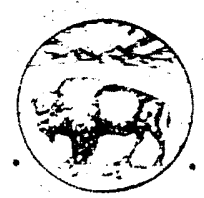




\section{GEOHYDROLOGY OF ROCKS PENETRATED BY TEST WELL \\ USW H-6, YUCCA MOUNTAIN, NYE COUNTY, NEVADA}

By R.W. Craig, U.S. Geological Survey, and

R.L. Reed, Fenix \& Scisson, Inc.

USGS/WRIR $--89-4025$

DE92 003375

\section{U.S. GEOLOGICAL SURVEY}

Water-Resources Investigations Report 89-4025

Prepared in cooperation with the

U.S. DEPARTMENT OF ENERGY

\section{DISCLAIMER}

This report was prepared as an account of work sponsored by an agency of the United States Government. Neither the United States Government nor any agency thereol, nility or responsiemployees, makes any warranty, express or implied, or assumes any legal apparatus, product, or bility for the accuracy, completeness, or usefulness of any informate privately owned rights. Referprocess disclosed, or represents that its use would not inf or service by trade name, trademark, ence herein to any specific commercial product, process, or serice by timply its endorsement, recommanufacturer, or otherwise does not necessarily constitute or inply its endorser. The views mendation, or favoring by the United States Government or ans state or reflect those of the

and opinions of authors expressed herein thereof.

Denver, Colorado

1991

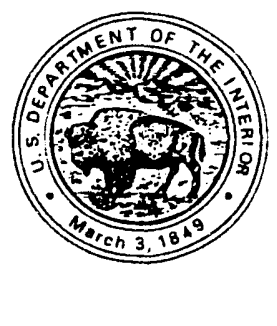




\section{U.S. DEPARTMENT OF THE INTERIOR}

MANUEL LUJAN, JR., Secretary

U.S. GEOLOGICAL SURVEY

Dallas L. Peck, Director

For additional information write to:

Chief, Hydrologic Investigations Program

Yucca Mountain Project Branch

U.S. Geological Survey

Box 25046, Mail Stop 421

Federal Center

Denver, CO 80225-0046
Copies of this report can

be purchased from:

U.S. Geological Survey

Books and Open-File Reports Section

Box 25425, Mail Stop 517

Federal Center

Denver, CO 80225-0425 
Figure 1. Map showing location of test well USW H-6 and other test

2. Diagram showing well construction-

3-27. Graphs showing:

3. Analysis of water-level drawdown, pumping test 1: depth interval from 526 to 1,220 meters; straight-line solution with dual-porosity model-..-.-

4. Analysis of water-level drawdown, pumping test 1: depth interval from 526 to 1,220 meters; Theis method with an arbitrarily assumed storage coefficient of about $4 \times 10^{-4}$

5. Analysis of water-leve1 drawdown, pumping test 1: depth interval from 526 to 1,220 meters; Theis method-_.

6. Comparison of pumping-test data from three wells completed in apparent dual-porosity systems with data for pumping test 1 of test well USW H-6.....

7. Analysis of water-level drawdown, pumping test 2: depth interval from 526 to 1,220 meters; straight-

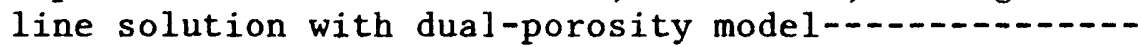

8. Borehole-flow survey, showing percentage of pumping rate produced by intervals

9. Water-1 rel recove y, pumping test 2: depth interval from 526 to 1,220 meters 
Figures 3-27. Graphs showing--Continued

Page

10. Sketch of design for pumping test 3- 18

11. Sketch of design for pumping test 4- 19

12. Analysis of water-level drawdown, pumping test 3: depth interval from 753 to 834 meters; straight-line solution with dual-porosity model--.-- 20

13. Residual drawdown, recovery test 3 : depth interval 753 to 834 meters--.- 20

14. Water-level drawdown, pumping test 4: depth interval from 608 to 645 meters-a. 21

15. Water-level recovery, recovery test 4: depth interval from 608 to 645 meters-ar 22

16. Analysis of packer-injection test 1: depth interval from 581 to 607 meters-a 23

17. Data for packer-injection test 2: depth interval from 606 to 640 meters-a. 24

18. Analysis of packer-injection test 3: depth interval from 649 to 683 meters-a. 24

19. Analysis of packer-injection test 3A: depth interval from 649 to 683 meters-

20. Analysis of packer-injection test 4: depth interval from 686 to 753 meters-D 25

21. Data for packer-injection test 5: depth interval from 753 to 787 meters-a. 26

22. Analysis of packer-injection test 6: depth interval from 804 to 838 meters-a. 26

23. Analysis of packer-injection test 7: depth interval from 835 to 869 meters- 27

24. Analysis of packer-injection test 8: depth interval from 871 to 1,220 meters---.-.-

25. Data for packer-injection test 9: depth interval from 1,118 to 1,152 meters-

26. Analysis of packer-injection test 10 : deptin interval from 1,155 to 1,220 meters-- 28

27. Relation between stratigraphy, fractures, welding, relatively porous rocks, and major water production--

TABLES

Table 1. Summary of major stratigraphic units penetrated by test well USW H-6-1 6

2. Water-level measurements- 8

3. Results of packer-injection tests-a 31

4. Comparison of calculated values of transmissivity determined from pumping tests and the borehole-flow survey to those determined from packer-injection tests- 32

5. Results of chemical analysis of water sample collected during pumping of depth interval from 526 to 1,220 meters---- 


\section{METRIC CONVERSION TABLE}

For those readers who prefer to use inch-pound rather than metric units, conversion factors for the terms used in this report are listed below:

Metric unit

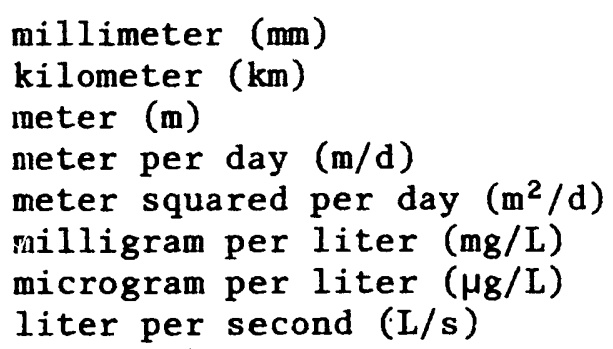

${ }^{1}$ Approximate for concentrations of dissolved solids less than about 7,000 milligrams per liter
Multiply by

0.03937

0.6214

3.281

3.281

10.76

$1_{1}$

${ }^{1} 1$

15.85

0.2642

${ }^{\circ} \mathrm{F}=1.8{ }^{\circ} \mathrm{C}+32$
To obtain inch-pound unit

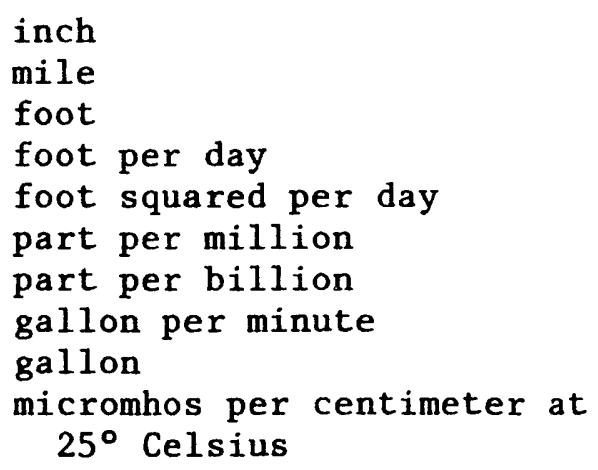

degree Fahrenheit $\left({ }^{\circ} \mathrm{F}\right)$ 


\title{
GEOHYDROLOGY OF ROCKS PENETRATED BY TEST WELL USW H-6, YUCCA MOUNTAIN, NYE COUNTY, NEVADA
}

By R.W. Craig and R.L. Reed

\begin{abstract}
Test well USW H-6 is one of several wells drilled in the Yucca Mountain area near the southwestern part of the Nevada Test Site for investigations related to isolation of high-level nuclear wastes. This well was drilled to a depth of 1,220 meters. Rocks penetrated are predominantly ash-flow tuffs of Tertiary age, with the principal exception of dacitic(?) lava penetrated at a depth from 877 to 1,126 meters. The composite static water level was about 526 meters below the land surface; the hydraulic head increased slightly with depth.

Most permeability in the saturated zone is in two fractured intervals in Crater Flat Tuff. Based on well-test data using the transitional part of a dual-porosity solution, an interval of about 15 meters in the middle part of the Bullfrog Member of the Crater Flat Tuff has a calculated transmissivity of about 140 meters squared per day, and an interval of about 11 meters in the middle part of the Tram Member of the Crater Flat Tuff has a calculated transmissivity of about 75 meters squared per day. The upper part of the Bullfrog Member has a transmissivity of about 20 meters squared per day. The maximum likely transmissivity of any rocks penetrated by the test well is about 480 meters squared per day, based on a recharge-boundary model. The remainder of the open hole had no detectable production. Matrix hydraulic conductivity ranges from less than $5 \times 10^{-5}$ to $1 \times 10^{-3}$ meter per day.

Ground water is a sodium bicarbonate type that is typical of water from tuffaceous rocks of southern Nevada. The apparent age of the water is about 14,600 years.
\end{abstract}

\section{INTRODUCTION}

The U.S. Geological Survey is conducting investigations to determine the geologic and hydrologic suitability of Yucca Mountain, Nevada, as a possible site for a mined geologic repository for high-level nuclear wastes. These investigations are being conducted under the auspices of the U.S. Department of Energy, Nevada Operations Office under Interagency Agreement DE-AIO8$78 E T 44802$ and are part of the Nevada Nuclear Waste Storage Investigations project. This report presents hydrologic information obtained from test well USW $\mathrm{H}-6$, one of a series of test wells drilled on and near Yucca Mountain. 


\section{Purpose and Scope}

The purpose of this report is to characterize the geohydrology of saturated volcanic rocks penetrated by test well USW H-6. Drilling test wells designed for hydrologic testing is one approach for determining the suitability of the hydrologic system for storage of high-level nuclear waste at the Yucca Mountain site. This report contains hydrologic interpretations of saturated rocks penetrated in test well USW H-6 based on data obtained from borehole tests and supported by geological and geophysical information.

\section{Location of Study Area}

Test well USW H-6 is located on Yucca Mountain in Nye County, Nevada, in the southern part of the State, about $145 \mathrm{~km}$ northwest of Las Vegas, at Nevada State Coordinate System, central zone N 763,299 ft and E 554,075 ft (fig. 1). The altitude of land surface at the site is $1,302 \mathrm{~m}$ above sea level. Test well USW H-6 is west of the area on Yucca Mountain being considered as a possible waste repository. The well site is in a small canyon that drains eastward into Solitario Canyon, a larger, south-trending drainage system that is bounded on the eastern side by a large fault scarp (Lipman and McKay, 1965). The test well was drilled principally to determine if geohydrologic conditions east of the fault scarp, as determined by data from other test wells, also extend to the west.

\section{Geohydrologic Setting}

The area around Yucca Mountain is a desert region within the Basin and Range physiographic province. Rock units exposed in this area are sedimentary rocks of Precambrian and Paleozoic age, volcanic and sedimentary rocks of Tertiary age, and alluvial and playa deposits of Quaternary age (Winograd and Thordarson, 1975; Byers and others, 1976). Tertiary volcanic and sedimentary rocks, as well as previously deformed Precambrian and Paleozoic strata, have undergone large-scale normal block-faulting, that began with Miocene volcanism and continued into thr: Quaternary Period. This large-scale normal blockfaulting, which produred the Basin and Range topography, is the most prominent tectonic feature in the area (Winograd and Thordarson, 1975, p. C13).

Yucca Mountain is composed primarily of Tertiary ash-flow tuffs. Test wells drilled on Yucca llountain have not penetrated older rocks below the Tertiary tuff units, but test well UE-25p非, about $5.7 \mathrm{~km}$ southeast of test well USW H-6 and about $1.5 \mathrm{~km}$ east of Yucca Mountain, penetrated Paleozoic dolomite at a depth of $1, \dddot{\alpha} 44 \mathrm{~m}$, on what is probably a structural high (Craig and Johnson, 1984).

Block-faulting, typical of the Basin and Range province, produced the present topography of Yucca Mourtain. The western edge oi the highest ridge of Yucca Mountain is bounded by a large fault scarp (Lipman and McKay, 1965). This scarp forms the eastern boundary to Solitario Canyon. 


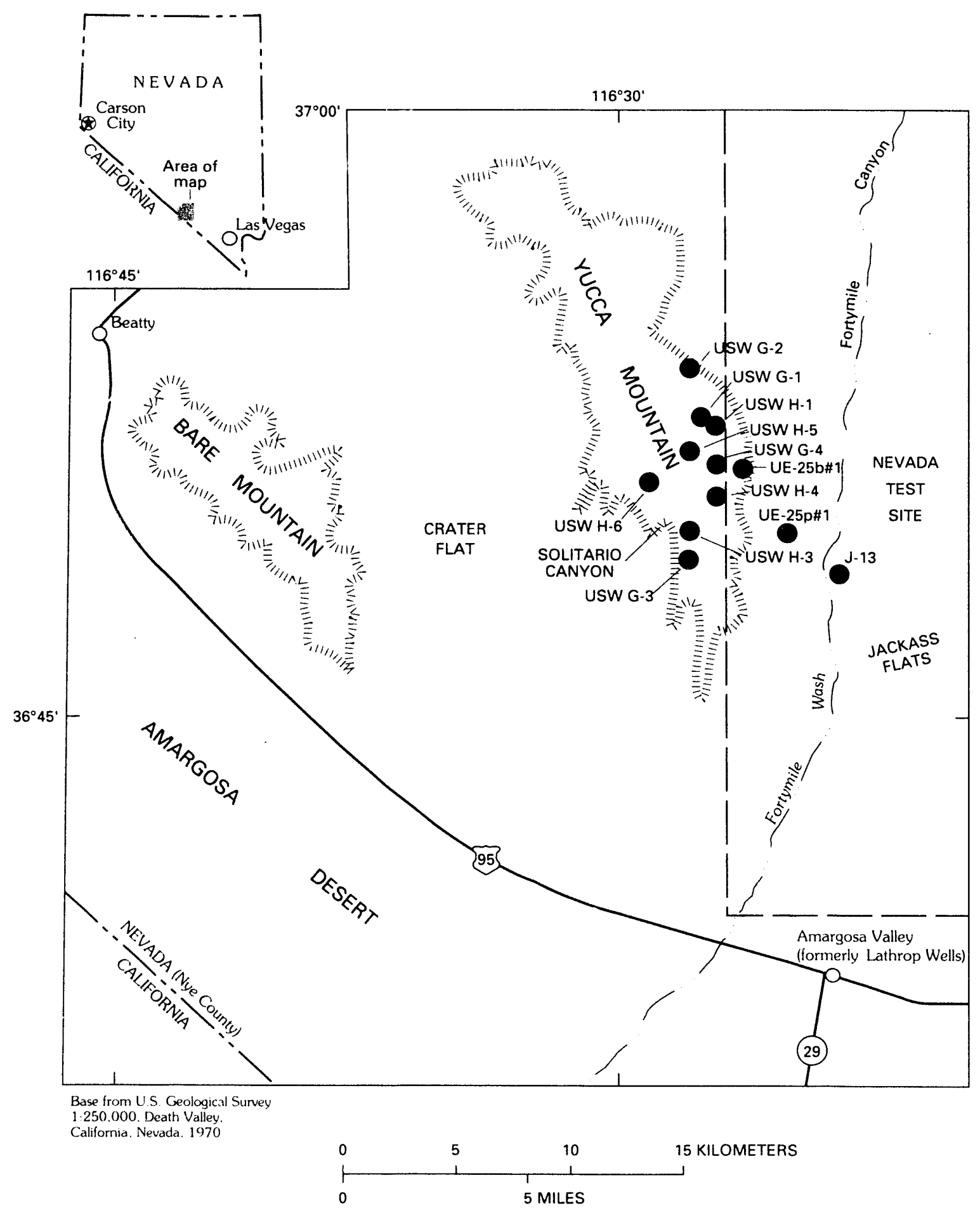

Figure 1.--Location of test well USW H-6 and other test wells in the vicinity. 
Annual precipitation for the Yucca Mountain area is between $150 \mathrm{~mm}$ and $200 \mathrm{~mm}$ (Quiring, 1965). Precipitation is mainly from winter and spring frontal systems and summer thunderstorms. Because the area has a desert climate, and because evapotranspiration occurs rapidly, it is estimated that only about 3 percent of annual precipitation recharges the ground-water system (Rush, 1970). This recharge probably occurs only during major runoffproducing events.

The general direction of flow in the ground-water system beneath Yucca Mountain is south-southeastward; the flow eventually discharges in the Armagosa Desert to the southwest (Wadde11, 1982, p. 3). Data indicate that rocks beneath Solitario Canyon are not a pathway for the flow of ground water, although the fault scarp is orientated in a southerly direction. Instead, the fault probably is a barrier to the eastward movement of ground water. This condition is indicated by a higher $(40$ to $50 \mathrm{~m}$ ) water table to the west and north of the fault scarp than to the east of the fault scarp (Robison, 1984).

\section{DRILLING AND TESTING OPERATIONS}

The drilling of test well USW H-6 began on August 7, 1982. A total depth of $1,220 \mathrm{~m}$ was reached on September 30, 1982, without unusual drilling problems. The well was rotary drilled, using an air-foam fluid consisting of air, detergent, and water to minimize formation damage. A lithium chloride tracer was added to water used in drilling and testing operations. Circulation was lost for about $30 \mathrm{~min}$ at a depth of $1,130 \mathrm{~m}$. The well was cored a total of $67 \mathrm{~m}$ at selected intervals at depths from 333 to $1,220 \mathrm{~m}$. The well construction is shown in figure 2, and bit and casing data are listed in the following table:

\begin{tabular}{rccc}
\hline $\begin{array}{c}\text { Drilled } \\
\text { interval } \\
\text { (meters) }\end{array}$ & $\begin{array}{c}\text { Bit } \\
\text { diameter } \\
\text { (millimeters) }\end{array}$ & $\begin{array}{c}\text { Cased } \\
\text { interval } \\
\text { (meters) }\end{array}$ & $\begin{array}{c}\text { Casing inside } \\
\text { diameter } \\
\text { (millimeters) }\end{array}$ \\
\hline $0-99$ & 914 & $0-9$ & 746 \\
$9-102$ & 559 & $0-95$ & 381 \\
$102-583$ & 375 & $0-581$ & 250 \\
$583-1216$ & 222 & open hole & \\
$1216-1220$ & 156 & open hole & \\
\hline
\end{tabular}

A directional survey showed that the maximum hole deviation was 1.5 degrees. The bottom survey station at a deoth of $1,204 \mathrm{~m}$ indicated that the well deviation was $16 \mathrm{~m}$ from vertical, at a direction of $\mathrm{N} .88^{\circ} 21^{\prime} \mathrm{W}$. After drilling was completed, a suite of geophysical logs was run, casing was perforated, and the well was hydraulically tested. Testing consisted of pumping and recovery tests, a borehole-flow survey, and packer-injection tests. A composite water sample for chemical analysis was collected near the end of pumping. A detailed drilling and testing history is contained in the files of the engineering firm of Fenix \& Scisson, Inc. (consultant of U.S. Department of Energy), Las Vegas, Nev. 


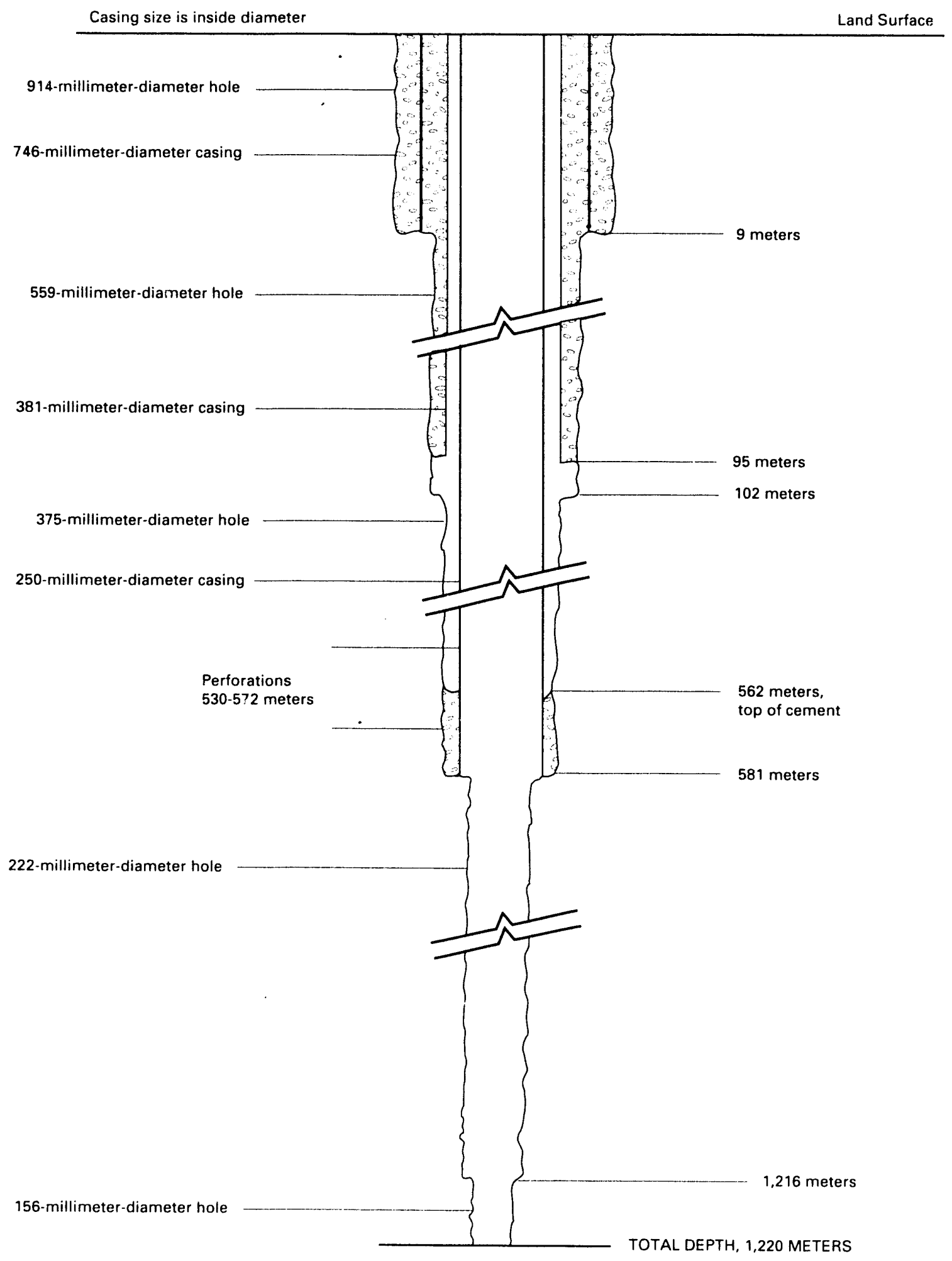

Figure 2.--Well construction. 


\section{Stratigraphy and Lithology}

Rocks penetrated by test well USW $\mathrm{H}-6$ are mainly nonwelded to densely welded ash-flow tuff units of Tertiary age. Exceptions to the sequence of ash-flow tuff units are a dacitic(?) lava, penetrated in the depth interval from 877 to $1,126 \mathrm{~m}$, and seven tuff units that are thin-bedded or relatively reworked and unlithified or both; these tuff units are present at the base of most stratigraphic units (one is included in the tuffaceous beds of Calico Hills). A summary of major stratigraphic units and contacts is presented in table 1 .

\section{Table 1.--Summary of major stratigraphic units penetrated by test well USW H-6}

[Condensed from Craig and others, 1983]

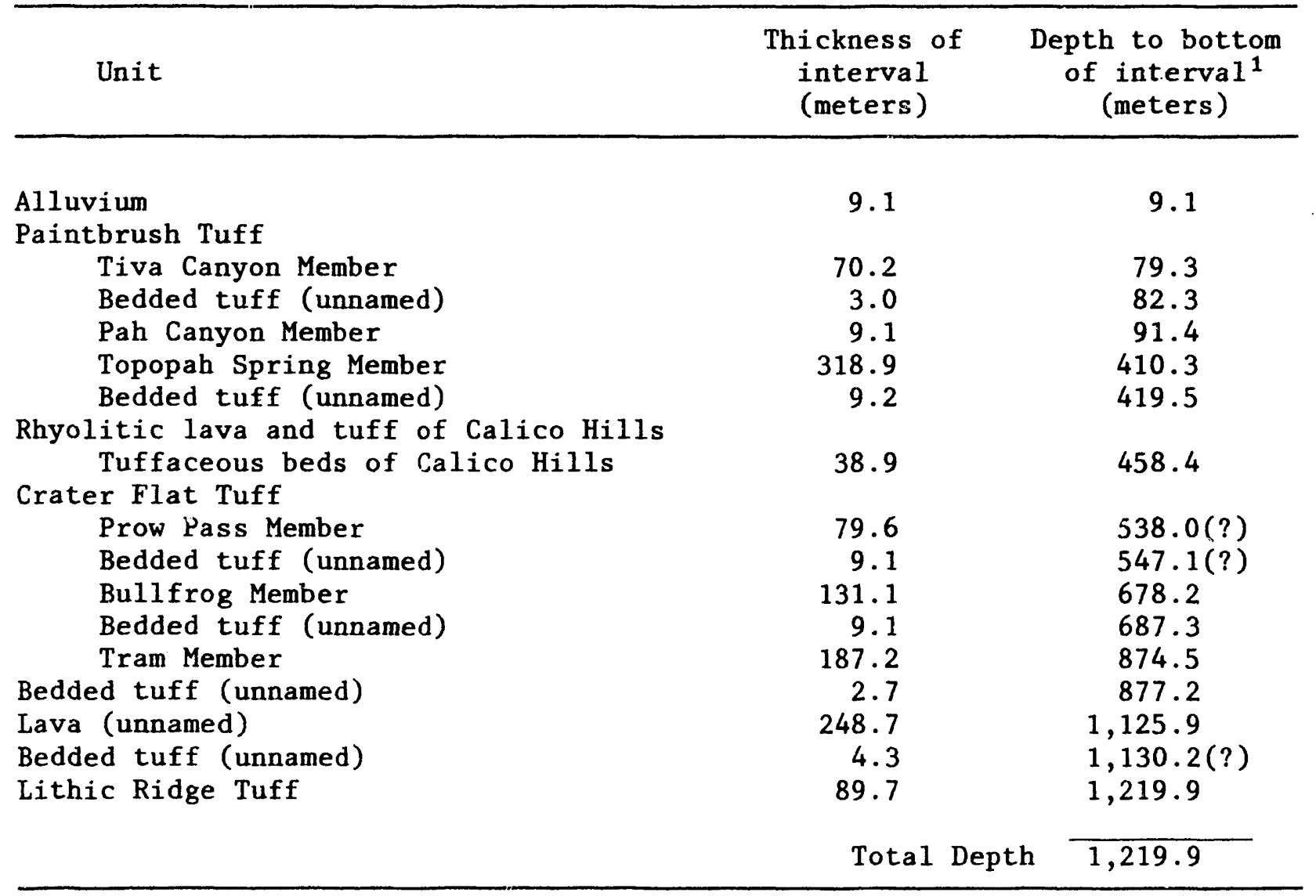

${ }^{1}$ Depth to bottom of interval is reported to 0.1 meter to correspond to thickness of intervals; actual depths are probably \pm 0.5 meter.

The thickest units penetrated by the test well were the Topopah Spring Member of Paintbrush Tuff, $319 \mathrm{~m}$ thick, and the dacitic(?) lava (unnamed), $249 \mathrm{~m}$ thick. The degree of welding is greatest in the Topopah Spring Member of the Paintbrush Tuff, which is characteristically moderately to densely welded. The least welded tuff units are the tuffaceous beds of Calico Hills 
and the upper and lower parts of the Tram Member of the Crater Flat. Tuff. Bedded tuff units are nonwelded and slightly indurated. Other tuff units in the sequence are mostly partially to moderately welded.

\section{Water Levels}

Water-level measurements were made in test well USW H-6 during drilling and hydraulic testing to: (1) Locate possible perched water zones;

(2) determine the depth of the top of the saturated zone; and (3) determine any dirferences in hydraulic head at specific depth intervals. About 3 months after completion of the packer-injection tests, the bottom $33 \mathrm{~m}$ of the well was isolated from the upper part of the well by means of a packer. Periodic water-level measurements were then made in both intervals.

No perched-water zones were detected while drilling. A television-camera log of the unsaturated part of the hole showed a small quantity of water flowing from fractures in the depth interval from 305 to $335 \mathrm{~m}$. Whether the observed water was drilling fluid or perched water is not known.

The first indication of reaching the saturated zone was a driller's report that water was thought to have been reached at a depth of about $526 \mathrm{~m}$, because of a slight increase in penetration rate and pump pressure. This depth was later confirmed by wacer-level measurements, as well as by geophysical well logs. These water-level measurements are listed in table 2 . They are divided into two groups: the first group consists of composite water levels; the second group consists of water levels measured in isolated intervals during packer-injection testing. The last measurement in each group is a measurement of water level above and below the packer installed at a depth of $1,187 \mathrm{~m}$; these measurements were made to determine if hydraulic head near the bottom of the well was different from the composite hydraulic head above.

Results of water-level measurements indicated that the top of the saturated zone was at a depth of $526 \mathrm{~m}$ (776 m above sea level) in the lower part of the Prow Pass Member of the Crater Flat Tuff. Measurements made during packer-injection tests indicate a slight decrease in hydraulic head with depth to about $800 \mathrm{~m}$, then an increase of about $1 \mathrm{~m}$ in the depth interval from 804 to $838 \mathrm{~m}$, followed by a slight decrease to the bottom of the well. The depth at which the apparent $1-m$ increase in hydraulic head occurred corresponds to slightly below the bottom of the producing zone during pumping. Measurements made on December 29, 1983, about 14 months after completion of testing, indicated that the hydraulic head in the bottom $33 \mathrm{~m}$ was $2.2 \mathrm{~m}$ higher than composite head for the remainder of the well. It was inferred that water-level measurements made during testing, especially in the lower $400 \mathrm{~m}$ of the well, were not made under true static conditions. Drilling and testing operations may have affected the water-levels. Measurements made in late 1983 were more representative of equilibrium confitions near the well. The hydraulic head probably increased slightly with depth rather than decreased with depth. It was possible, based on available data, that a minor increase in hydraulic head occurred near a depth of $800 \mathrm{~m}$. 
Table 2.--Water-level measurements

\begin{tabular}{|c|c|c|c|}
\hline Date & $\begin{array}{c}\text { Depth interval } \\
\text { (meters) }\end{array}$ & $\begin{array}{l}\text { Depth to water } \\
\text { (meters) }\end{array}$ & Method \\
\hline \multicolumn{4}{|c|}{ Composite levels } \\
\hline $\begin{array}{l}09 / 04 / 82 \\
09 / 05 / 82 \\
10 / 01 / 82 \\
10 / 06 / 82 \\
10 / 20 / 82 \\
12 / 15 / 82 \\
12 / 29 / 83\end{array}$ & $\begin{array}{l}525-583 \\
525-1583 \\
525-1,220 \\
525-1,220 \\
525-1,220 \\
525-1,220 \\
525-1,187\end{array}$ & $\begin{array}{l}525.4 \\
527 \\
525 \\
526.0 \\
526.0 \\
527.7 \\
526.4\end{array}$ & $\begin{array}{l}\text { Television camera } \\
\text { Fluid-density log } \\
\text { Fluid-Density log } \\
\text { Float switch } \\
\text { Do. } \\
\text { Do. } \\
\text { Do. }\end{array}$ \\
\hline \multicolumn{4}{|c|}{ Isolated intervals (packer-injection tests) } \\
\hline $\begin{array}{l}10 / 17 / 82 \\
10 / 18 / 82 \\
10 / 19 / 82 \\
10 / 27 / 82 \\
10 / 22 / 82 \\
10 / 23 / 82 \\
10 / 23 / 82 \\
10 / 24 / 82 \\
10 / 24 / 82 \\
10 / 25 / 82 \\
12 / 29 / 83\end{array}$ & 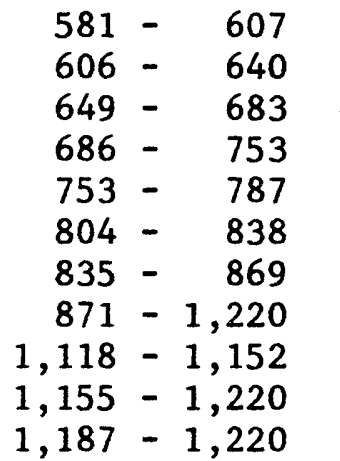 & $\begin{array}{l}525.6 \\
526.0 \\
526.2 \\
526.4 \\
526.5 \\
525.4+ \\
525.5 \\
525.6 \\
525.9 \\
526.5 \\
524.2\end{array}$ & $\begin{array}{c}\text { Float switch } \\
\text { Do. } \\
\text { Do. } \\
\text { Do. } \\
\text { Do. } \\
\text { Do. } \\
\text { Transducer } \\
\text { Transducer } \\
\text { Float switch } \\
\text { Do. } \\
\text { Do. }\end{array}$ \\
\hline
\end{tabular}

${ }^{1}$ Depths to water include a correction of 0.05 meter due to hole deviation from vertical between land $s$-face and the water table.

\section{Pumping and Recovery Tests, and Borehole-Flow Survey}

Two pumping tests and one recovery test were conducted in test well USW H-6 at the conclusion of drilling. During these tests, the well was cased to a depth of $581 \mathrm{~m}$, with casing perforated in the depth interval from 530 to $572 \mathrm{~m}$. The borehole was open to formation rock from a depth of $581 \mathrm{~m}$ to a total depth of $1,220 \mathrm{~m}$. The composite static water level prior to each pumping test was $526 \mathrm{~m}$ below the land surface ( $776 \mathrm{~m}$ above sea level). The pump setting was identical for both pumping tests, with intakes at $552 \mathrm{~m}$ below the land surface. As indicated by the borehole-flow survey, which was made during the second pumping test, production was limited to the saturated zone above a depth of $803 \mathrm{~m}$.

The fracture system in the aquifer was under confined conditions at the depths of primary production. Evidence for confined conditions consisted of small values of matrix hydraulic conductivity relative to values fracture hydraulic conductivity in the Crater Flat Tuff near the potentiomeiric surface and the lack of measurable bypass around packers during packer-injection testing near the top of the saturated zone. 
Pumping test 1 was conducted during October 1982 for 4,822 minutes at a rate of $28.4 \mathrm{~L} / \mathrm{s}$. Drawdown data were obtained for the first 4,184 minutes . At that time, the monitoring instrument was removed in preparation for a borehole-flow survey. Premature shutdown of the pump occurred at 4,822 minutes after pumping started. No recovery data were obtained, as the drawdown-monitoring instrument was still out of the well. Fumping test 2 was started 25 hours later, and conducted for 2,226 minutes at a rate of $26.6 \mathrm{~L} / \mathrm{s}$. Drawdown data were obtained for the first 116 minutes, and from 1,789 minutes after pumping started to the end of pumping. The drawdown-monitoring instrument was out of the well during an interval from 116 to 1,789 minutes while the temperature $\log$ and borehole-flow survey were made. Recovery of water level was monitored for 300 minutes after pumping stopped.

Analysis of data for pumping test 1 is shown in semilogarithmic form in figure 3; drawdown is along the vertical axis, and time is along the horizontal axis. The maximum drawdown measured was $17.8 \mathrm{~m}$ after 4,184 minutes. The data in figure 3 plot in two straight-line segments; the first segment was from about 0.7 to 2 minutes after pumping started, and the second segment was from 14 minutes to the end of test. Although the data plot is consistent with the early time and transitional time of a dual-porosity model, use of the first straight-line segment to calculate transmissivity results in an unrealistically large storage coefficient of greater than 1; the data probably were affected by wellbore storage and possibly by a variable flow rate during the first few minutes of the test.

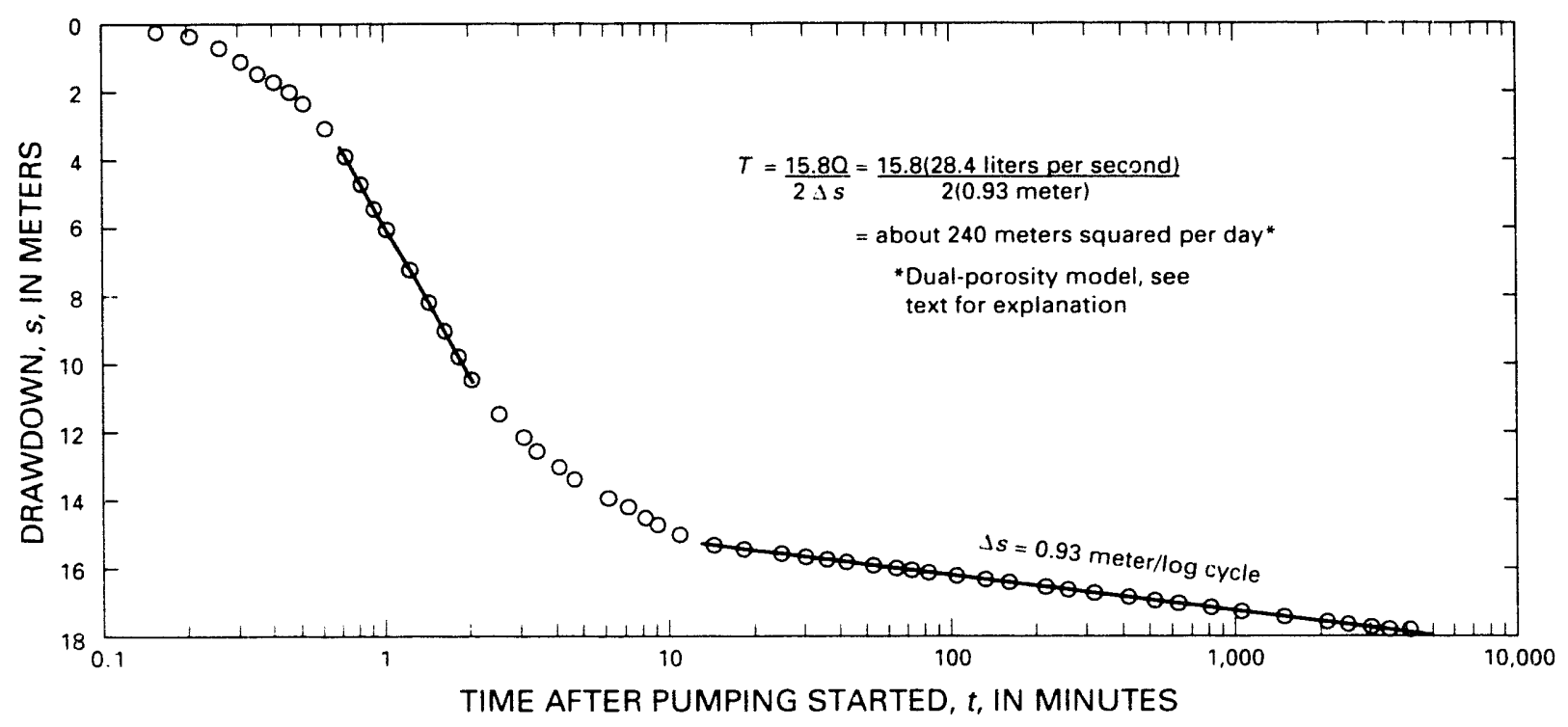

Figure 3.--Analysis of water-level drawdown, pumping tesc 1: depth interval from 526 to 1,220 meters; straight-line solution with dual-porosity model. 
The lack of a third straight-line segment indicates that, if the conceptual model is valid, late time was not reached, and analysis would be restricted to the data from the transitional period (second segment). However, data from the transitional period can be used to obtain an estimate of transmissivity, with some qualifying assumptions.

If fractures in a dual-porosity system do not have "fracture skin," the slope of the transitional-time data on a semilogarithmic plot will be one-half of the true slope of the late-time data (Moench, 1984, p. 840). Fracture skin is a thin incrustation of material with minimal permeability that is deposited on the matrix-fracture interface and that decreases flow between the matrix and fractures. If fracture skin is present, the slope of the second segment may be much less than one-half the slope of the late-time data.

Data for pumping test 1 shown in figure 3 fit the second straight-line segment with little deviation. Transmissivity, using data from 14 minutes to near the end of pumping at 4,184 minutes, is calculated to be about $240 \mathrm{~m}^{2} / \mathrm{d}$. This value, which is based on the assumption that no fracture skin exists, is one-half the value that would be calculated for the second straight-line segment by the method of Cooper and Jacob (1946):

$$
T=\frac{15.8 \Omega}{2 \Delta s}
$$

where $T=$ transmissivity, in meters squared per day;

$Q=$ discharge, in liters per second; and

$\Delta s=$ change in drawdown over one log cycle of time, in meters. The factor 2 doubles the slope of the transitional-time data to equal the assumed slope of late-time data.

Water entering the well was assumed to have been from fractures only; calculation of fracture hydraulic conductivity would require knowledge of the size of fracture apertures, but this information was not available.

One alternative interpretation involves hydrologic boundaries; after about 14 minutes of pumping (fig. 3), the slope may represent a recharge boundary. A large fault scarp (Lipman and McKay, 1965), is located approximately $1,000 \mathrm{~m}$ east or the well site at the land surface. At depths of primary production, 616 to $631 \mathrm{~m}$ and 777 to $788 \mathrm{~m}$ (see section entitled "Borehole-Flow Survey"), a fault dip of $60^{\circ}$ to the west (Lipman and McKay, 1965) would place the fault about 640 and $550 \mathrm{~m}$, respectively, from the well bore. This fault may have been a hydrologic boundary of increased transmissivity. Apparent transmissivity, based on this boundary model, and calculated by the method of Cooper and Jacob (1946) for the second line segment would be about $480 \mathrm{~m}^{2} / \mathrm{d}$. This alternative is less likely to be applicable than a dual-porosity model. Many pumping-test results for test wells in the Yucca Mountain area are similar to those for test well USW H- 6 (test well UE-25b非, Lobmeyer and others, 1983, p. 28; test well USW H-1, Rush and others, 1983, p. 25; test well USW G-4, Bentley, 1984, p. 27; and test well UE-25p非, Craig and Johnson, 1984, p. 13). It is doubtful that all tests in these test wells were affected by a recharge boundary but, rather, that some form of a fracture-controlled model is appropriate. 
A second alternative model is a homogeneous porous medium. Early-time data are attributed to wellbore storage and pumping-rate variations during startup. Later data may be matched with the Theis curve. Calculations of transmissivity and storage coefficient can be made by the standard Theis method (Ferris and others, 1962):

$$
T=\frac{6.9 \text { QW(u) }}{s}
$$

where $\quad T=$ transmissivity, in meters squared per day;

$Q=$ discharge, in liters per second;

$W(u)=$ well function of $u$, a dimensionless match point; and

$s=$ drawdown, a match point, in meters.

The storage coefficient is determined by the following equation:

$$
s=\frac{4 T t u}{r^{2}}
$$

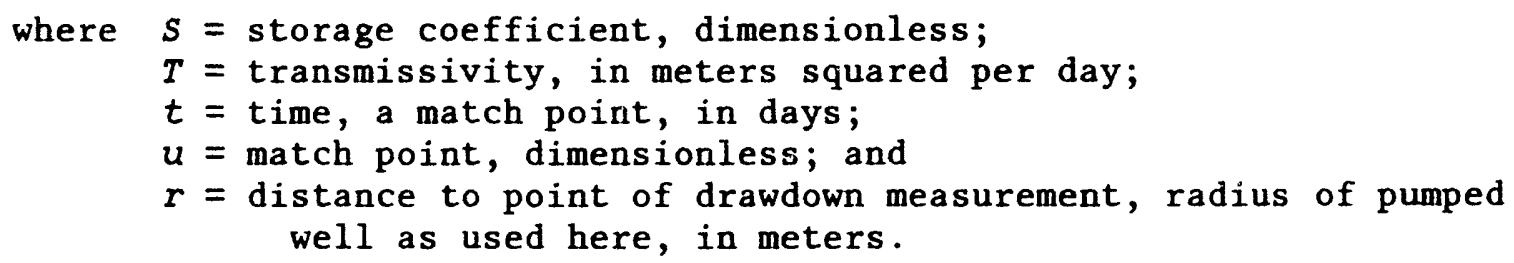

A limitation of this interpretation, using the data from pumping test 1 , is that, if a reasonable storage coefficient of about $4 \times 10^{-4}$ is arbitrarily assumed in order to guide the data match with the type curve, the fit is unsatisfactory (fig. 4). A better fit is shown in figure 5, but the calculated storage coefficient of $3 \times 10^{-10}$ is unrealistically small to have physical meaning. The late-time part of the Theis curve is relatively flat and the data-type curve match could be shifted horizontally slightly in either figure 4 or 5 , but the fit would still be unsatisfactory.

Similar plots of pumping-test data from three wells on the Nevada Test Site are instructive. The drawdown-versus-time data for these three wells and for pumping test 1 of test well USW H-6 are shown in figure 6 . Data from test well UE-25b 1 were used by Moench (1984) to illustrate the use of a dualporosity model with fracture skin. Test well UE-25b非 is $3.8 \mathrm{~km}$ northeast of test well USW H-6, on the east side of Yucca Mountain (fig. 1). This well is similar to USW H-6 in completion and is located in a similar geologic setting. The most significant differenc - is that test well UE-25b非 1 has five main zones of production, whereas test well USW H-6 has two. Data for well 67-68 and 88-66 are from data in figures 11 and 17 in Winograd and Thordarson (1975). These wells are about $50 \mathrm{~km}$ to the southeast and northeast, respectively, and are completed in fractured carbonate rocks of Paleozoic age. All four wells had a similar response, one that is consistent with a dual-porosity model. Apparent storage coefficients calculated by matching the transitional-time 


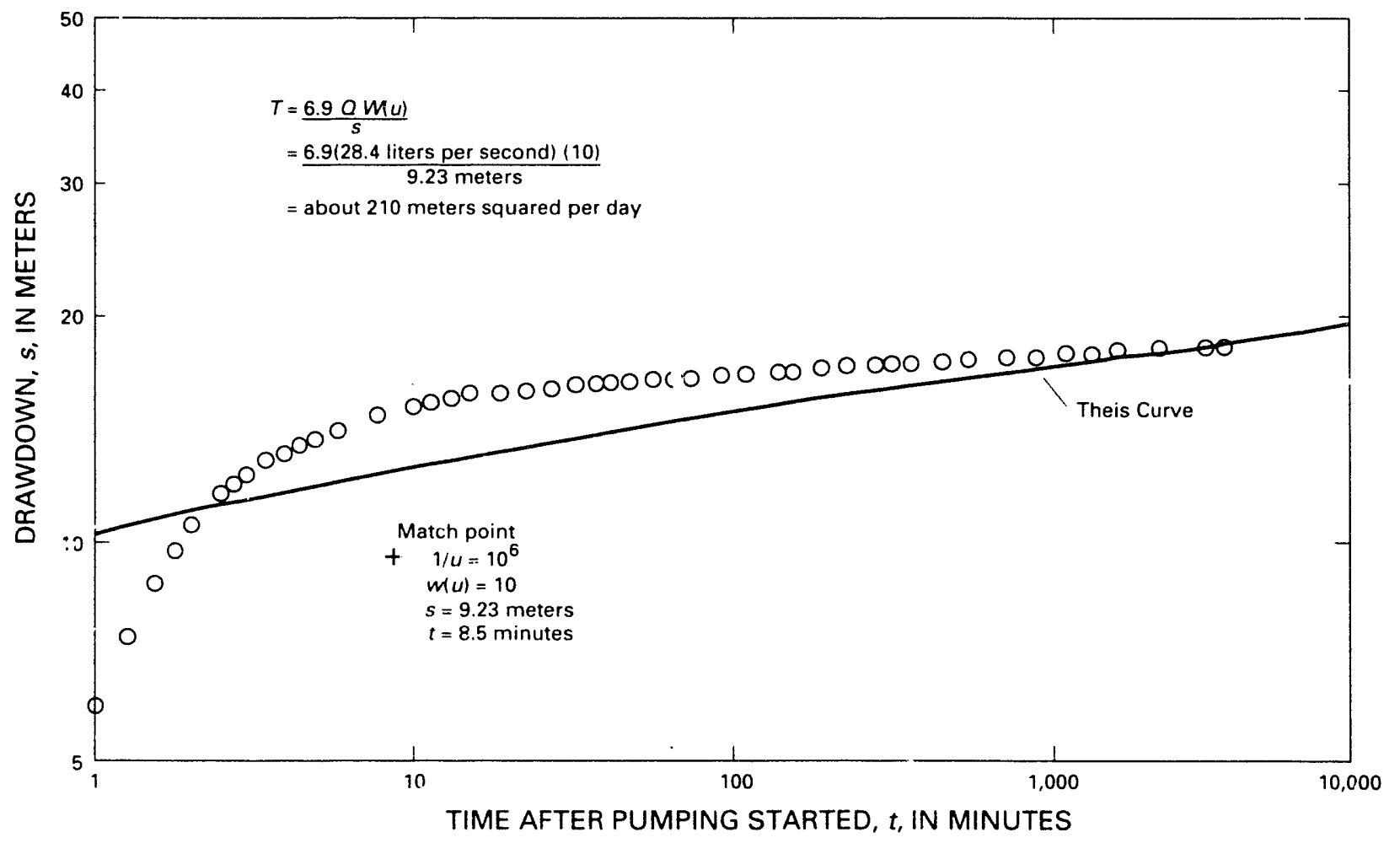

Figure 4.--Analysis of water-level drawdown, pumping test 1: depth interval from 526 to 1,220 meters; Theis method with an arbitrarily assumed storage coefficient of about $4 \times 10^{-4}$.

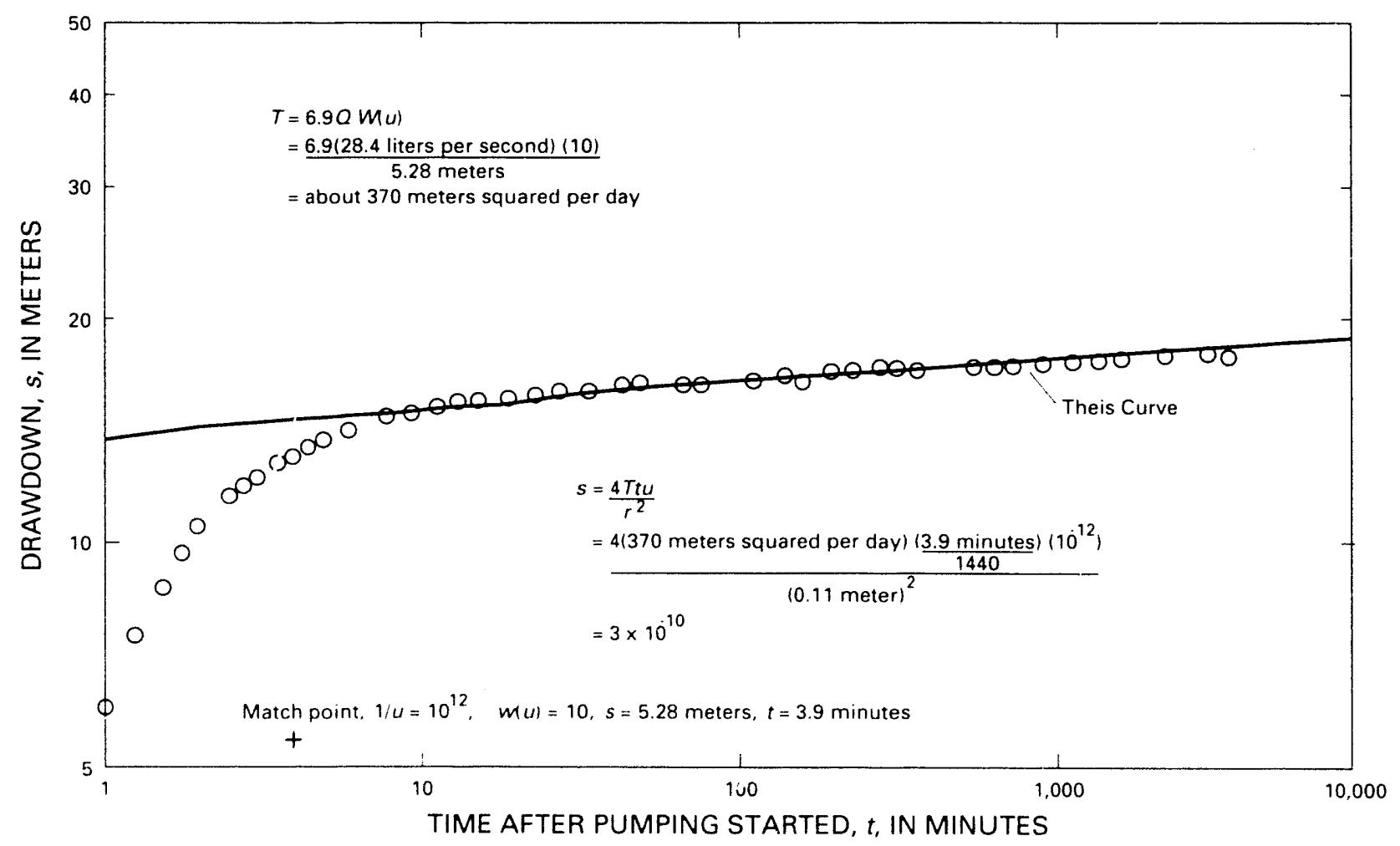

Figure 5.--Analysis of water-level drawdown, pumping test 1: depth interval from 526 to 1,220 meters; Theis method. 


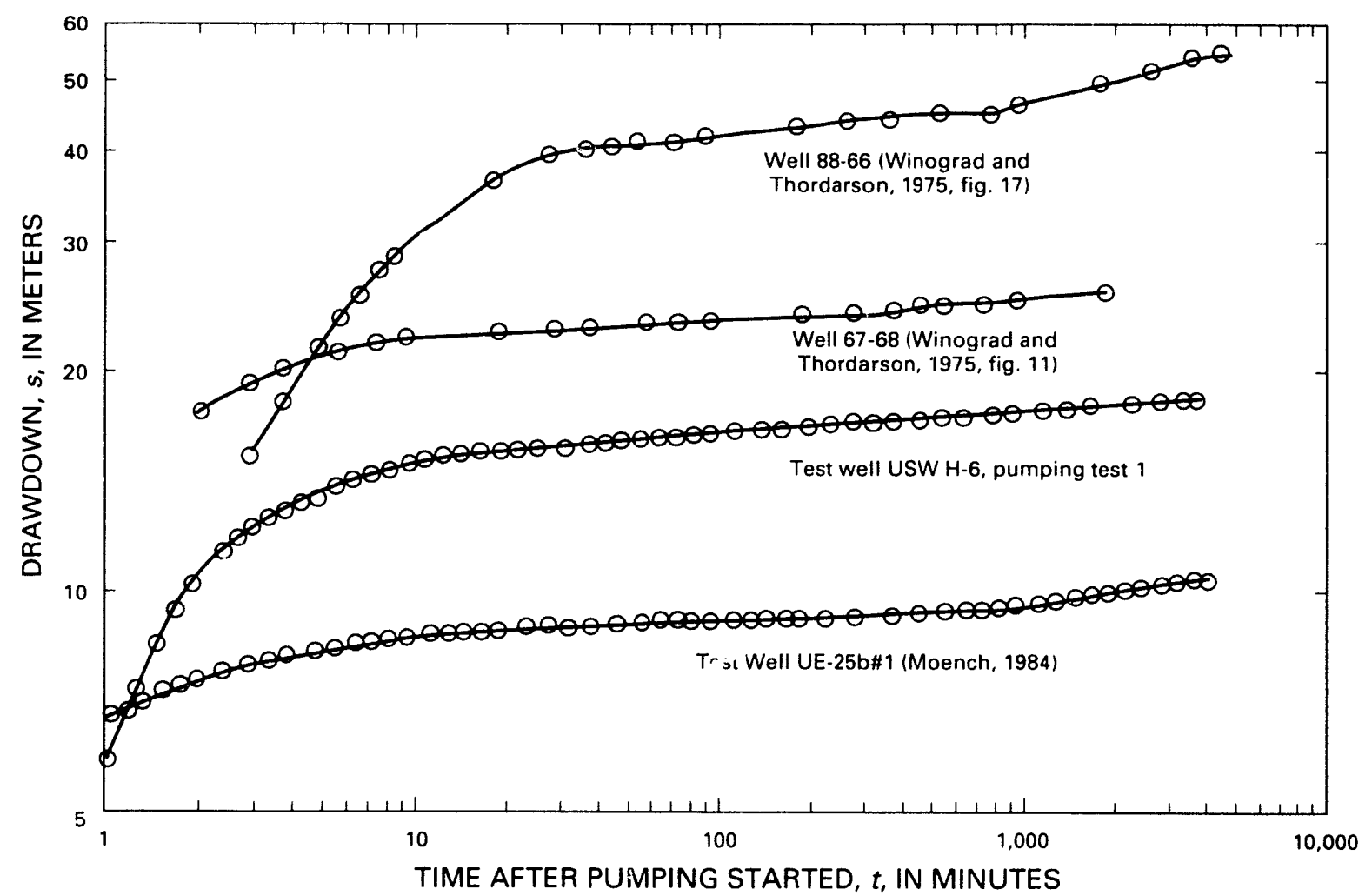

Figure 6.--Comparison of pumping-test data from three wells completed in apparent dual-porosity systems with data for pumping test 1 of test well USW H-6.

data with the Theis curve ranged from $4 \times 10^{-9}$ to $1 \times 10^{-11}$. Although an analysis that is beyond the scope of this report would be required to confirm any relation between the apparent storage coefficient of transitional-time data and a dual-porosity model, a dual-porosity model probably is more appropriate for the analysis of pumping test 1 than that of homogeneous porous medium.

Results of pumping test 1 indicate that the most reasonable value of transmissivity probably is about $240 \mathrm{~m}^{2} / \mathrm{d}$. Transmissivity may be as large as $480 \mathrm{~m}^{2} / \mathrm{d}$, if a recharge-boundary model is applicable, and less than $240 \mathrm{~m}^{2} / \mathrm{d}$ if fracture skin is present and has affected the responses.

\section{Pumping Test 2}

Analysis of data for pumping test 2 is shown in figure 7. Data are similar to those from pumping test 1 . Transmissivity is calculated to be about $230 \mathrm{~m}^{2} / \mathrm{d}$ using a dual-porosity model without fracture skin as was used in the analysis of test 1 in figure 3. The calculated transmissivity using a recharge-boundary model is about $460 \mathrm{~m}^{2} / \mathrm{d}$. Ending data of pumping test 2 
(fig. 7) were anomalous. These data did not plot on a continuation of a straight line from data prior to 116 minutes, and they also indicated a steeper slope for a part of the data. The anomalies are attributed to inaccuracy in re-positioning the drawdown-monitoring instrument after a borehole-flow survey and to water-sampling operations that affected the discharge rate.

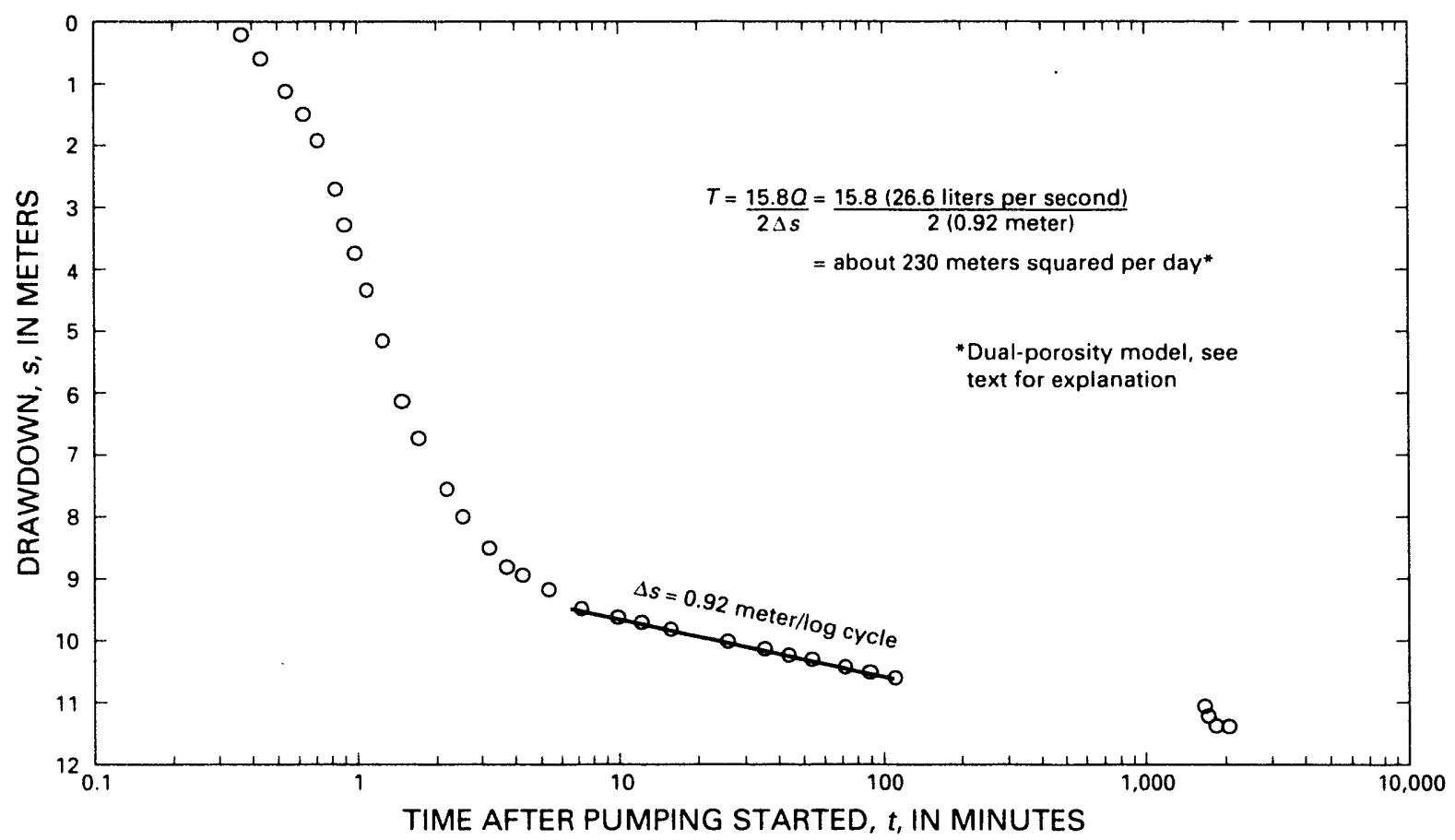

Figure 7.--Analysis of water-level drawdown, pumping test 2: depth interval from 526 to 1,220 meters; straight-line solution with dual-porosity model.

\section{Borehole-Flow Survey}

During pumping test 2 , a borehole-flow survey was made to determine which zones in the well were producing water. This survey was useful in determining relative productivity of the zones, and it served as a guide for selecting intervals for packer-injection tests. Iodine-131 was injected in small quantities into the well below the water table. Movement of the radioactive slug was monitored as it moved between two gamma-ray detectors. The rate of flow for each depth interval was calculated by multiplying the cross-sectional area of the borehole, as determined from a caliper $\log$, by the velocity of the slug. This process was repeated by moving the tool up the well, until all the zones of production were defined. A more complete description of the technique for borehole-flow surveys is given by Blankennagel (1967). Depth and corresponding stratigraphy versus percentage of total flow are shown in figure 8 . 


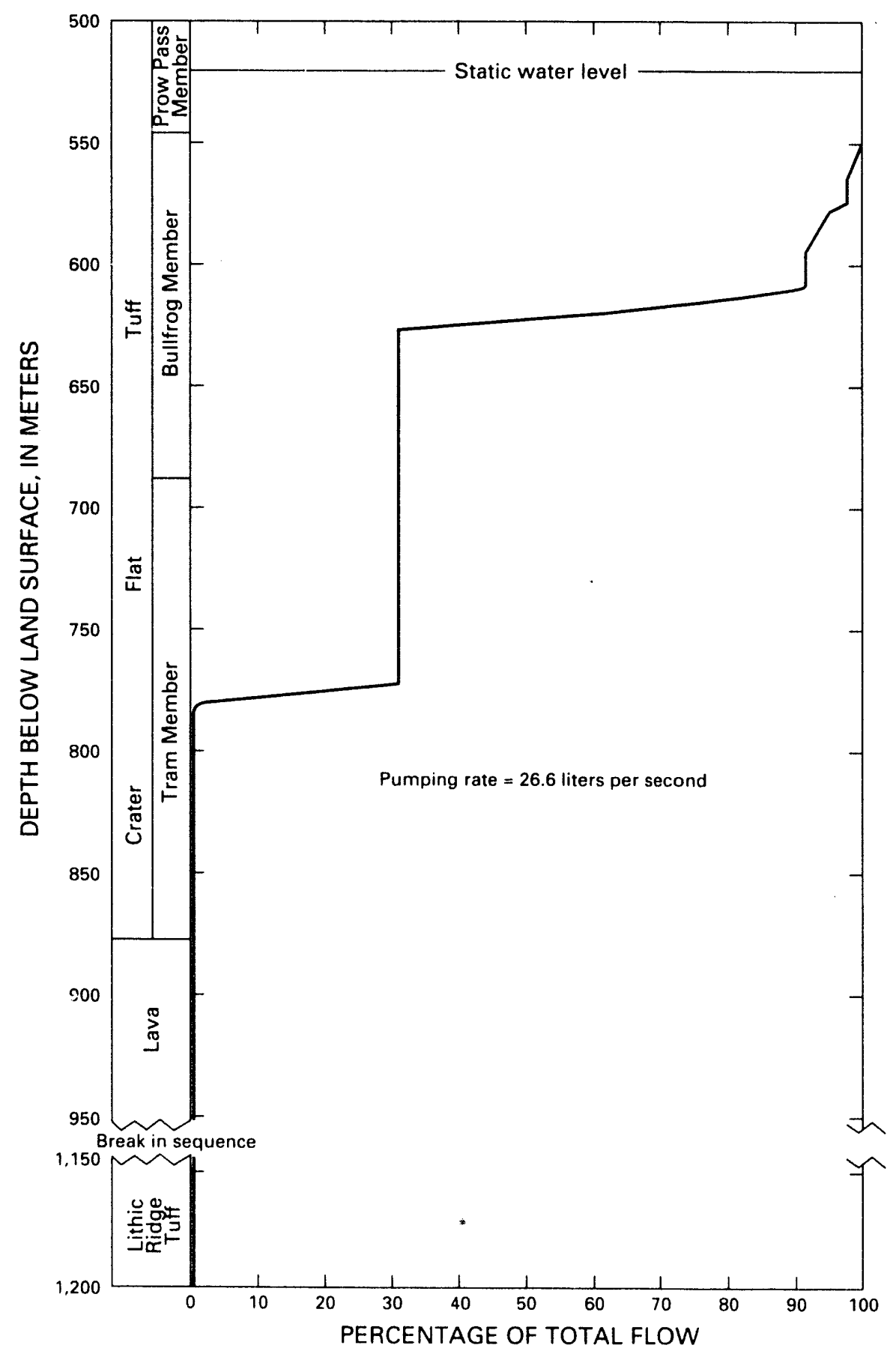

Figure 8.--Borehole-flow survey, showing percentage of pumping rate produced by intervals.

Results of the survey indicated two zones of primary production, both in the Crater Flat Tuff. During the survey, the total flow rate was $26.6 \mathrm{~L} / \mathrm{s}$. The depth interval from 616 to $631 \mathrm{~m}$ in the Bullfrog Member produced 60 percent of the total flow. The depth interval from 777 to $788 \mathrm{~m}$ in the 
Tram Member produced 32 percent of total flow. The depth interval from 581 to $604 \mathrm{~m}$ produced about 6 percent of the total flow; the depth interval behind perforated casing, above a depth of $572 \mathrm{~m}$, produced about 2 percent of the total flow. Both of these intervals were in the upper part of the Bullfrog Member. No measurable flow (greater than $0.05 \mathrm{~L} / \mathrm{s}$ ) was detected below a depth of $803 \mathrm{~m}$.

\section{Recovery Test 2}

Data for recovery test 2 are shown in figure 9, as residual drawdown versus time since pumping started, divided by time since pumping stopped.

The authors cannot explain the abnormally rapid recovery rate, nor did chey find an applicable explanation in the literature. The anomalous recovery rates does not appear to be due to the entry of lower density water into the well during the pumping period.

... Some mechanism other than temperature-induced density changes must be operating. Outgassing has not been noted in the sampled waters. Until the significance of the anomalous recovery rate is understood, the authors elect not to utilize transmissibility values obtained from the recovery curves.

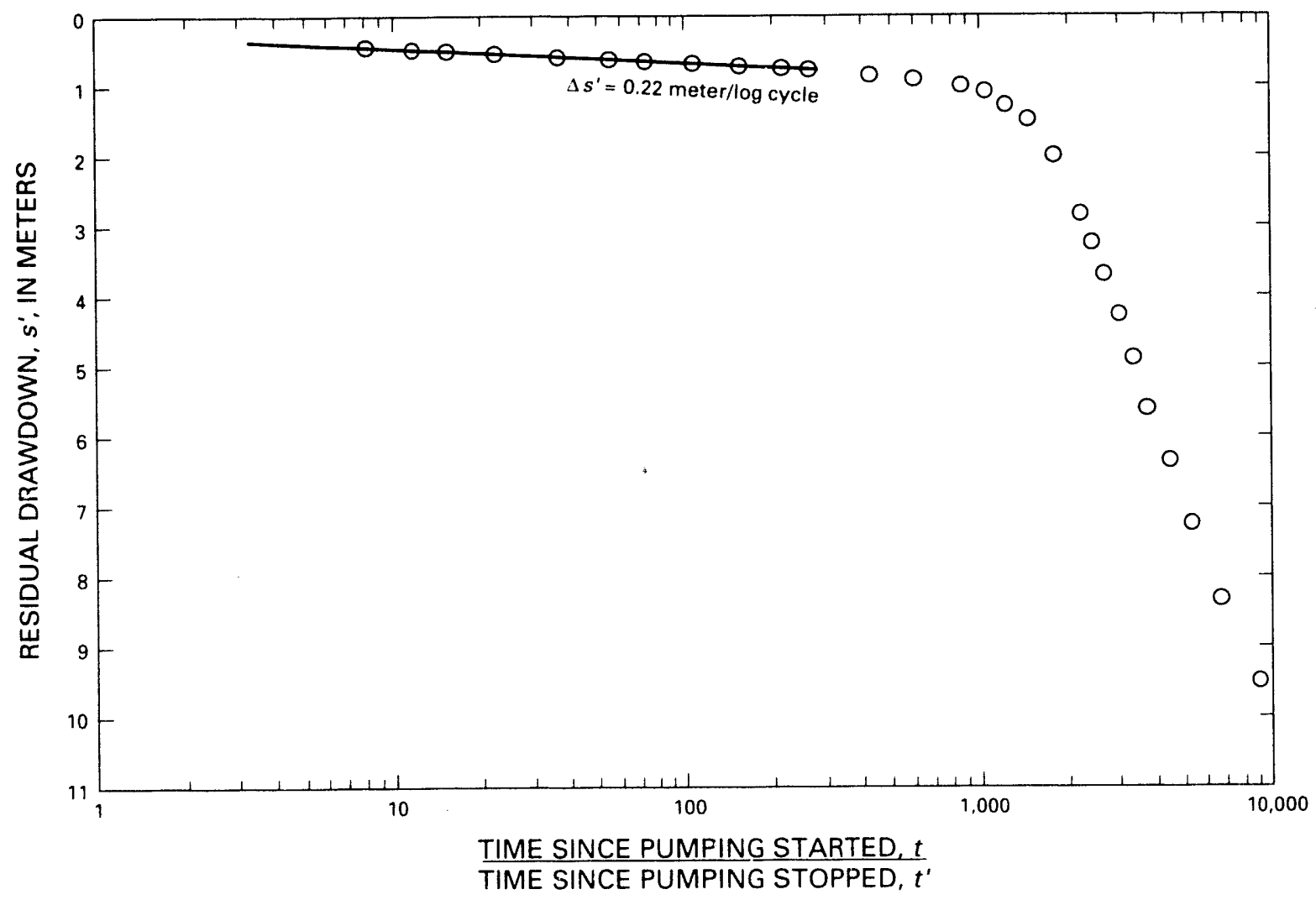

Figure 9.--Water-level recovery, pumping test 2: depth interval from 526 to 1,220 meters. 
The above statement, from Winograd and Thordarson (1975, p. 25) describes the dilemma of these authors; they were referring to six different pumping tests conducted in fractured carbonate rocks of Paleozoic age, which all had responses similar to those of test well USW H-6. Data for each test indicated an abnormally rapid recovery during the first few minutes of the recovery period. In addition, the slope of late-time recovery data (small values of $\left.t / t^{\prime}\right)$ was less than the corresponding times of drawdown for each well, as was the case for test well USW H-6. The authors of the present report prefer to note that transmissivity calculated from recovery test 2 would be about four times greater than that calculated from drawdown data, and not use recoveryderived transmissivity further.

\section{Pumping and Recovery Tests 3 and 4}

During June and July 1984, additional pumping and recovery tests were conducted in the two depth intervals that yielded the most production during previous pumping, as defined by the borehole-flow survey (fig. 8). The deepest interval was isolated by means of a retrievable plug placed below it at a depth of $834 \mathrm{~m}$ and a packer set above it at a depth of $753 \mathrm{~m}$. After testing the deeper interval, the upper interval was isolated by a retrievable plug at a depth of $645 \mathrm{~m}$ and a packer at a depth of $608 \mathrm{~m}$. Sketches of the designs for pumping tests 3 and 4 are shown in figures 10 and 11 .

Pumping test 3 tested the depth interval from 753 to $834 \mathrm{~m}$. The interval was pumped at a rate of $13.4 \mathrm{~L} / \mathrm{s}$ for 15,540 minutes. Analys is of dxawdown data (fig. 12) indicated that calculated transmissivity of this interval is $76 \mathrm{~m}^{2} / \mathrm{d}$, based on a dual-porosity model without fracture skin. This value is in agreement with a calculated transmissivity of about $75 \mathrm{~m}^{2} / \mathrm{d}$, based on pumping tests 1 and 2 , and the borehole-flow survey. Late-time data consistent with typical dual-porosity characteristics were not observed, and data scatter was greater during pumping test 3 than during previous tests.

Data for recovery test 3 are shown in figure 13. The data indicate that the water level recovered rapidly, rose to about $8 \mathrm{~m}$ above pre-pumping water level at 2.5 minutes after pumping stopped, and then declined to slightly below the pre-pumping level. The response probably was not representative of natural conditions, such as temperature changes. The basis for the foregoing conclusion is: (1) During a period of pumping prior to pumping test 3 , the pump stopped inadvertently, and cecovery was recorded on an analog recorder that indicated no recovery above pre-pumping level; (2) any expansion resulting from temperature changes in the water column while pumping would not account for the measured response. The cause of the erratic response during recovery test 3 is unknown.

Pumping test 4 was conducted in the depth interval from 608 to $645 \mathrm{~m}$. The interval was pumped at $14.5 \mathrm{~L} / \mathrm{s}$ for 1,385 minutes, at which time the pump shut off. The pump was re-started within a few minutes at an increased rate of $14.8 \mathrm{~L} / \mathrm{s}$ and was pumped for an additional 14,315 minutes. Data are shown in figure 14 as a continuous test. The data indicate an unusual response during early time that was similar to inertial effects modeled by Bredehoeft and others (1966), but a 22-minute period of pumping (fig. 14) after completion of recovery test 4 did not have the same response. Possibly, the variable-speed 


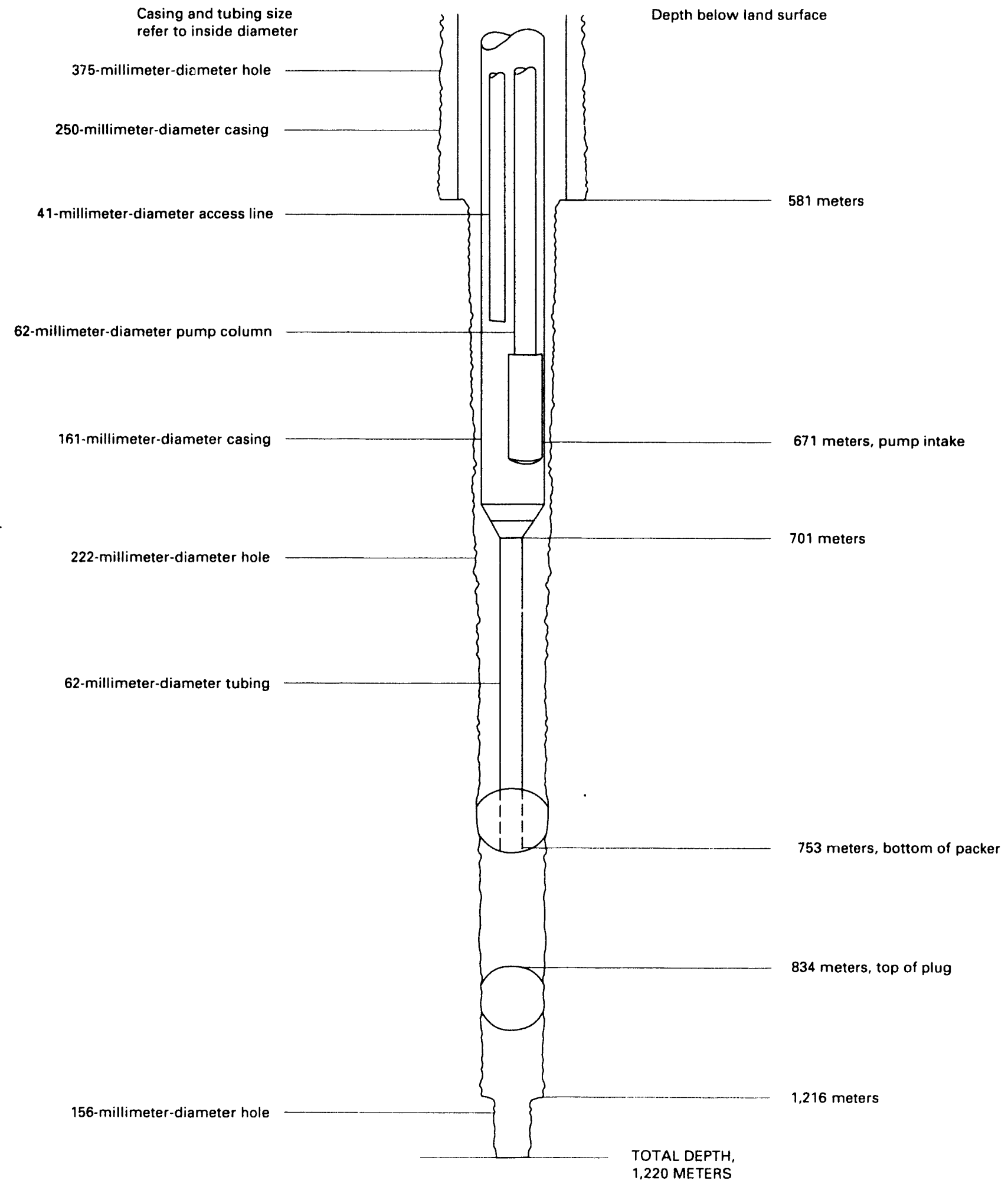

Figure 10.--Sketch of design for pumping test 3 . 


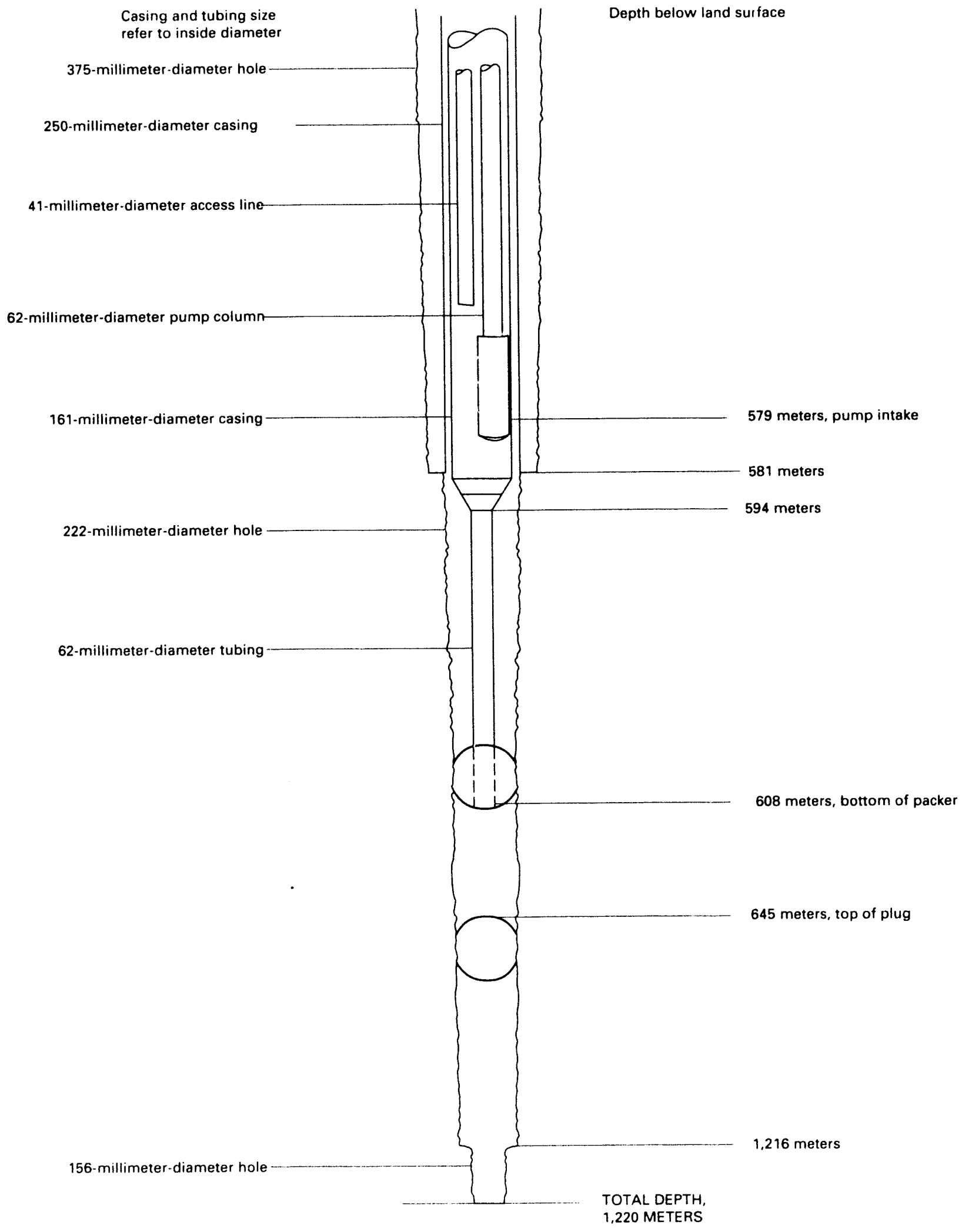

Figure 11.--Sketch of design for pumping test 4. 


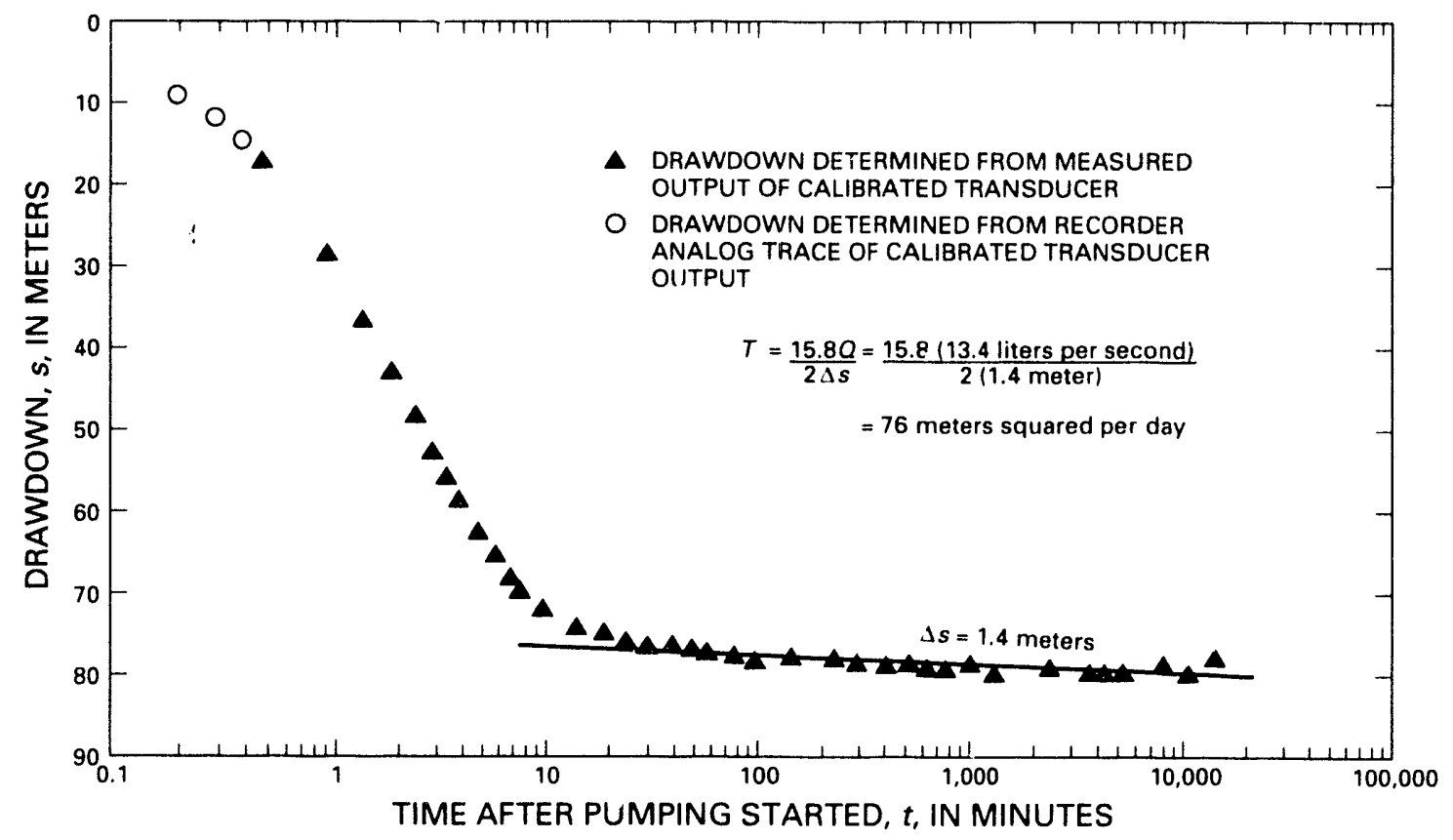

Figure 12.--Analysis of water-level drawdown, pumping test $3:$ depth interval from 753 to 834 meters; straight-line solution with dual-porosity model.

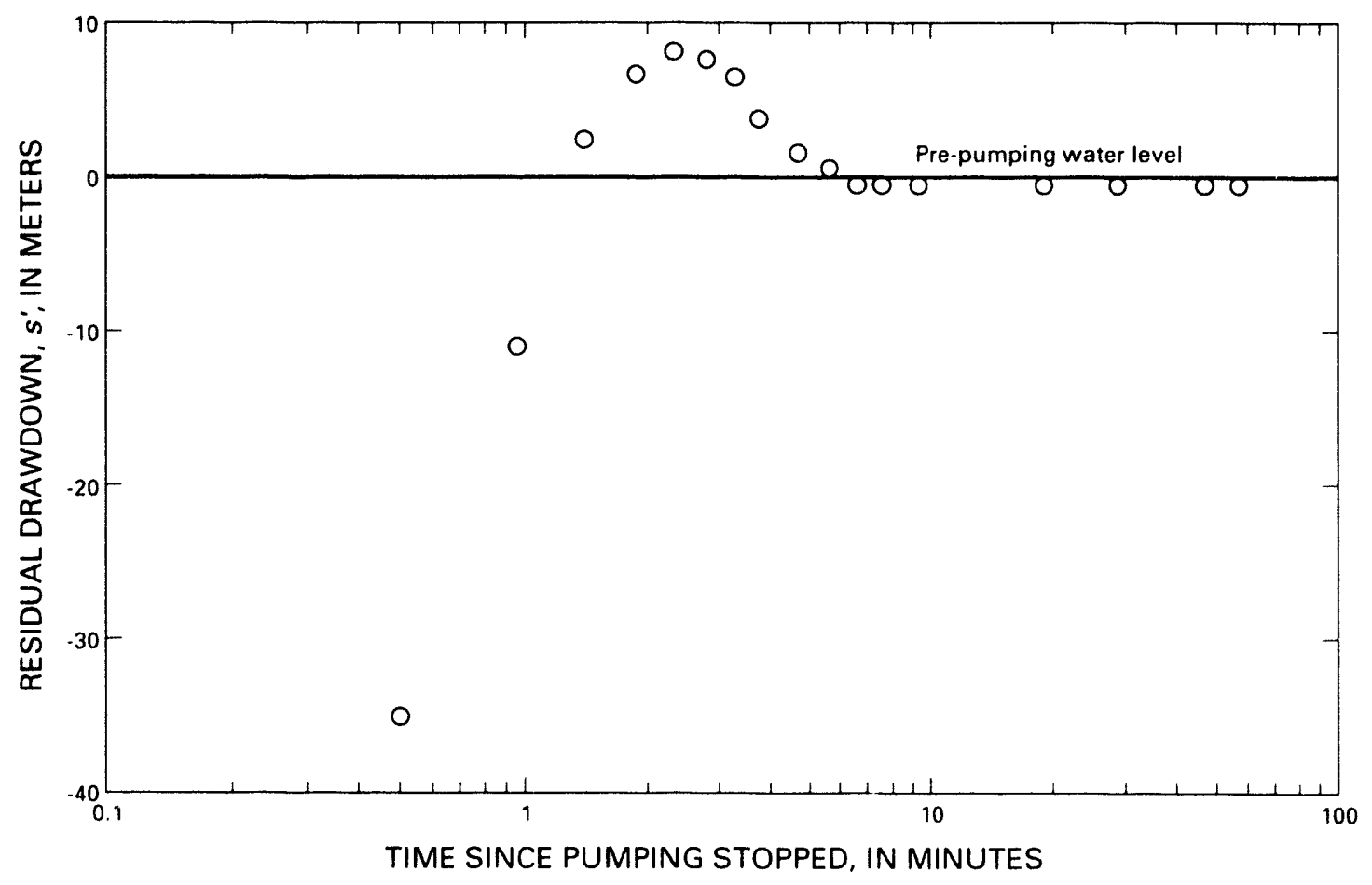

Figure 13.--Residual drawdown, recovery test 3: depth interval 753 to 834 meters. 


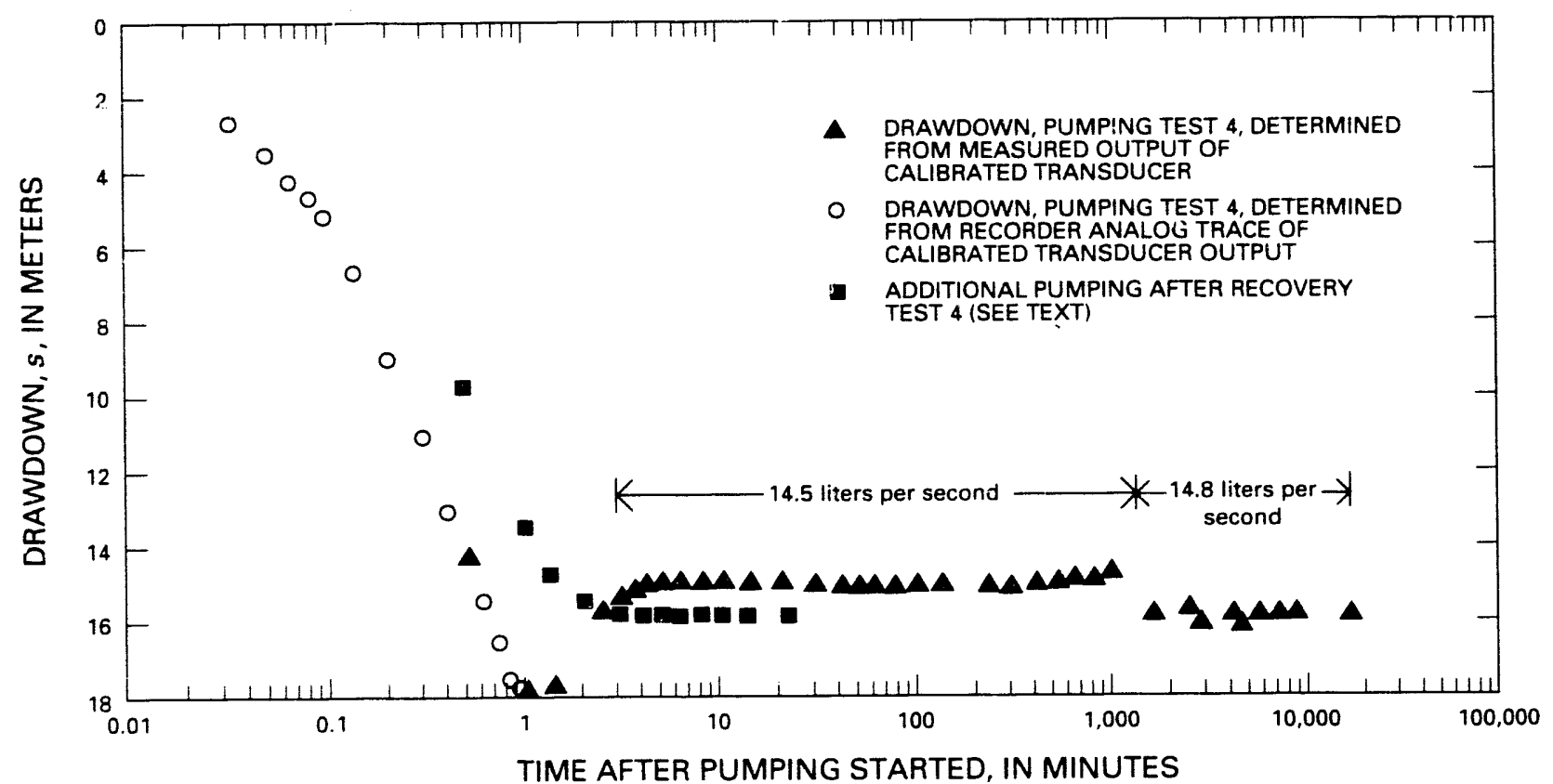

Figure 14.--Water-level drawdown, pumping test 4: depth interval from 608 to 645 meters.

pump control was adjusted (unnoticed) by support personnel resulting in less discharge about 1 minute after pumping started during pumping test 4. An analysis of drawdown data was not made because of the lack of slope in the data. The lack of slope may indicate substantial transmissivity, but recovery-test data, as discussed below, are consistent with recovery test 2 .

Recovery test 4 was monitored for 30 minutes; results are shown in figure 15 as residual drawdown versus time since pumping started divided by time since pumping stopped. Recovery was rapid, as in recovery test 2 . The slope of the line shown in figure 15 indicates a transmissivity of about four times the expected value, based on pumping tests 1 and 2 , but the value is consistent with the results of recovery test 2 .

\section{Packer-Injection Tests}

Packer-injection (slug) tests were conducted in various intervals of the well for two purposes: (1) To obtain data on distribution of hydraulic head; and (2) to obtain data for determination of distribution of transmissivity. Tests were conducted either for intervals isolated between packers or for intervals from the bottom packer to the bottom of the hole. Water was injected by filling tubing with water that was connected to the packer tool and then opening the tool to either the between-packer interval or belowpacker interval, thus allowing the water to drain into the formation while the decline of hydraulic head was monitored by means of a pressure transducer 
suspended inside the tubing at a depth slightly below the normal static water level. Because the volume of water injected was relatively small, the radius of investigation was correspondingly small.

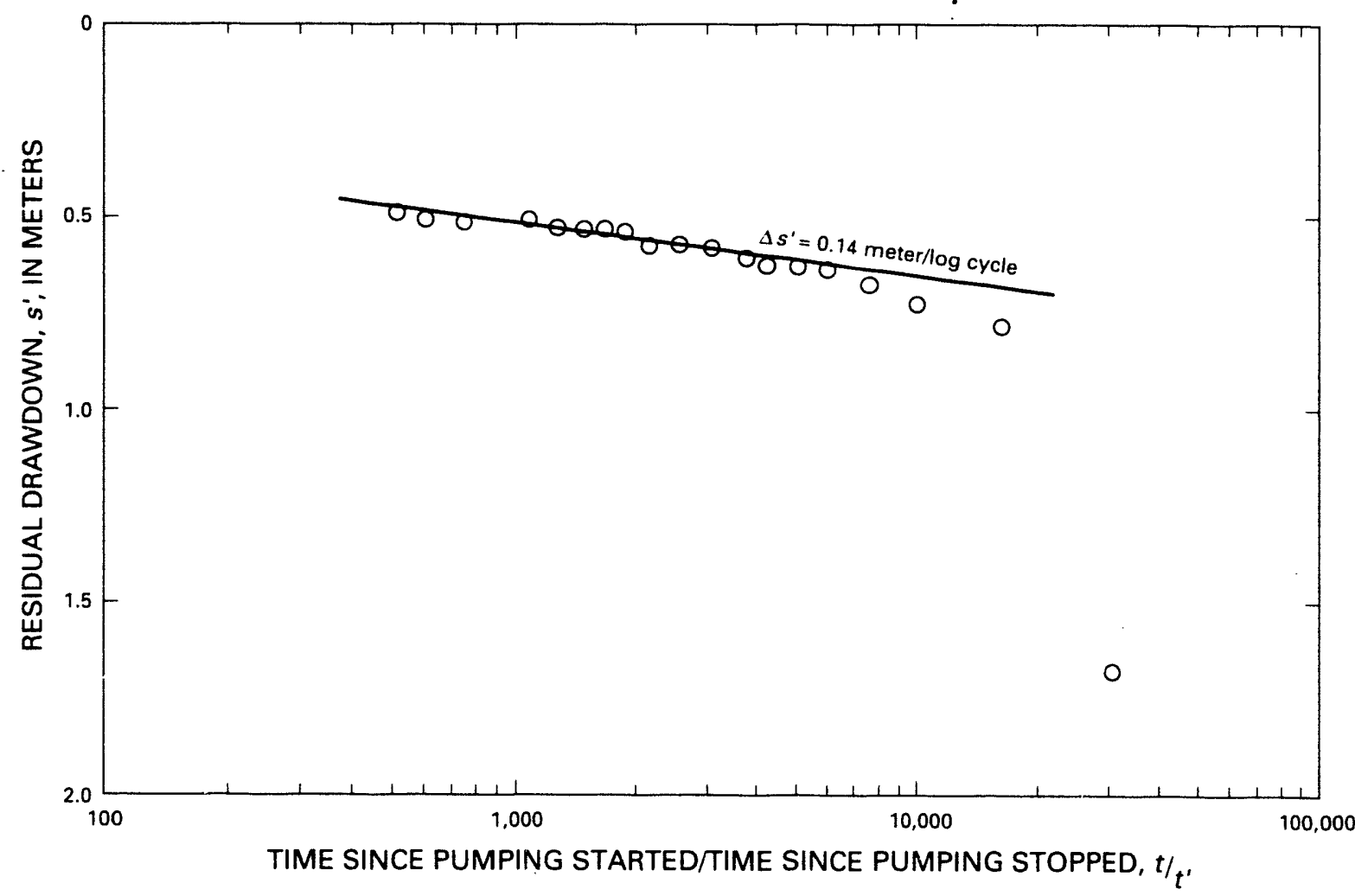

Figure 15.--Water-level recovery, recovery test 4: depth interval from 608 to 645 meters.

A limiting factor during iesting was the packer-injection tool. Because of the tool design, transmissivity values greater than about $5 \mathrm{~m}^{2} / \mathrm{d}$ could not be determined (C.0. Stokley, TAM International, oral commun., 1983). Apparently this was the case in two of the tests. This design limitation was used to determine if the decline in water level during testing resulted from formation characteristics or tool design: (1) If the static water level was reached in about 5 minutes or more, the response resulted from formation characteristics; and (2) if the static water level was reached in less than 5 minutes, response was affected by tool design and indicated that the transmissivity of the interval tested was greater than about $5 \mathrm{~m}^{2} / \mathrm{d}$.

The transmissivity of those intervals for which data could be matched to a type curve was determined by the methods of Cooper and others (1967) and Papadopulos and others (1973). Assumptions for their methods are discussed in these cited references. The decline of water level during each test, shown as the ratio of hydraulic head above the static water level at a given time (H), to hydraulic head above the static water level at the time of injection (Ho), 
versus time since injection began, is shown in semilogarithmic form in figures 16 to 26 . The ratio $\mathrm{H} / \mathrm{Ho}$ is along the vertical, or arithmetic, axis; $t$, time is along the horizontal, or logarithmic, axis. Hydraulic head above the static water level at the time of injection is shown as the value equal to Ho. Packer-injection tests 7 through 10 were made with about one-half the hydraulic head of packer-injection tests 1 through 6 in an attempt to decrease anomalous results (discussed below). A family of type curves was used to obtain a best fit with the data. A match line was selected on the logarithmic scale of the type-curve graph, with a value of 1.0 . Then, the corresponding match line of time, $t$, on the data curve was determined.

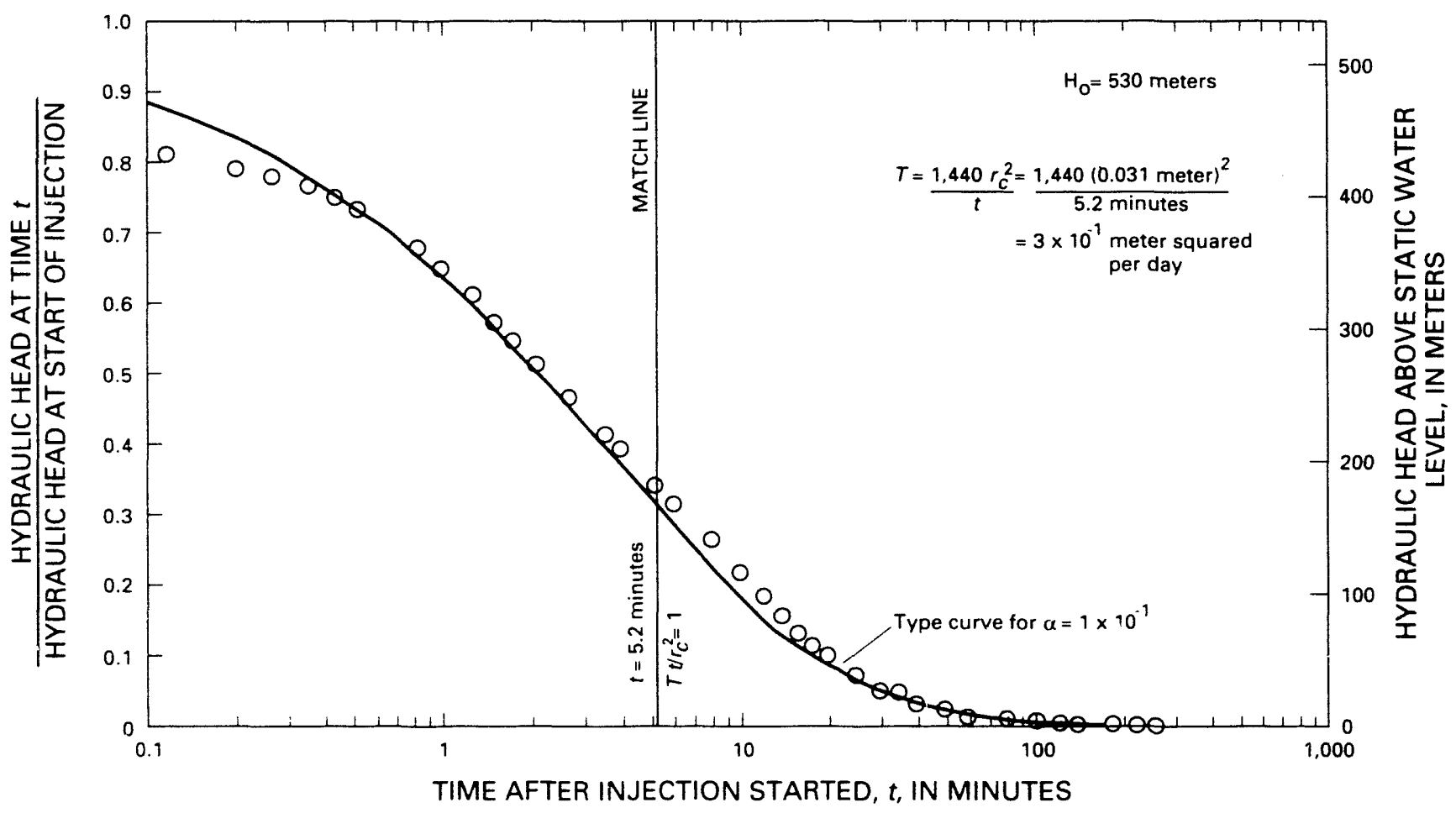

Figure 16.--Analysis of packer-injection test 1: depth interval from 581 to 607 meters. 


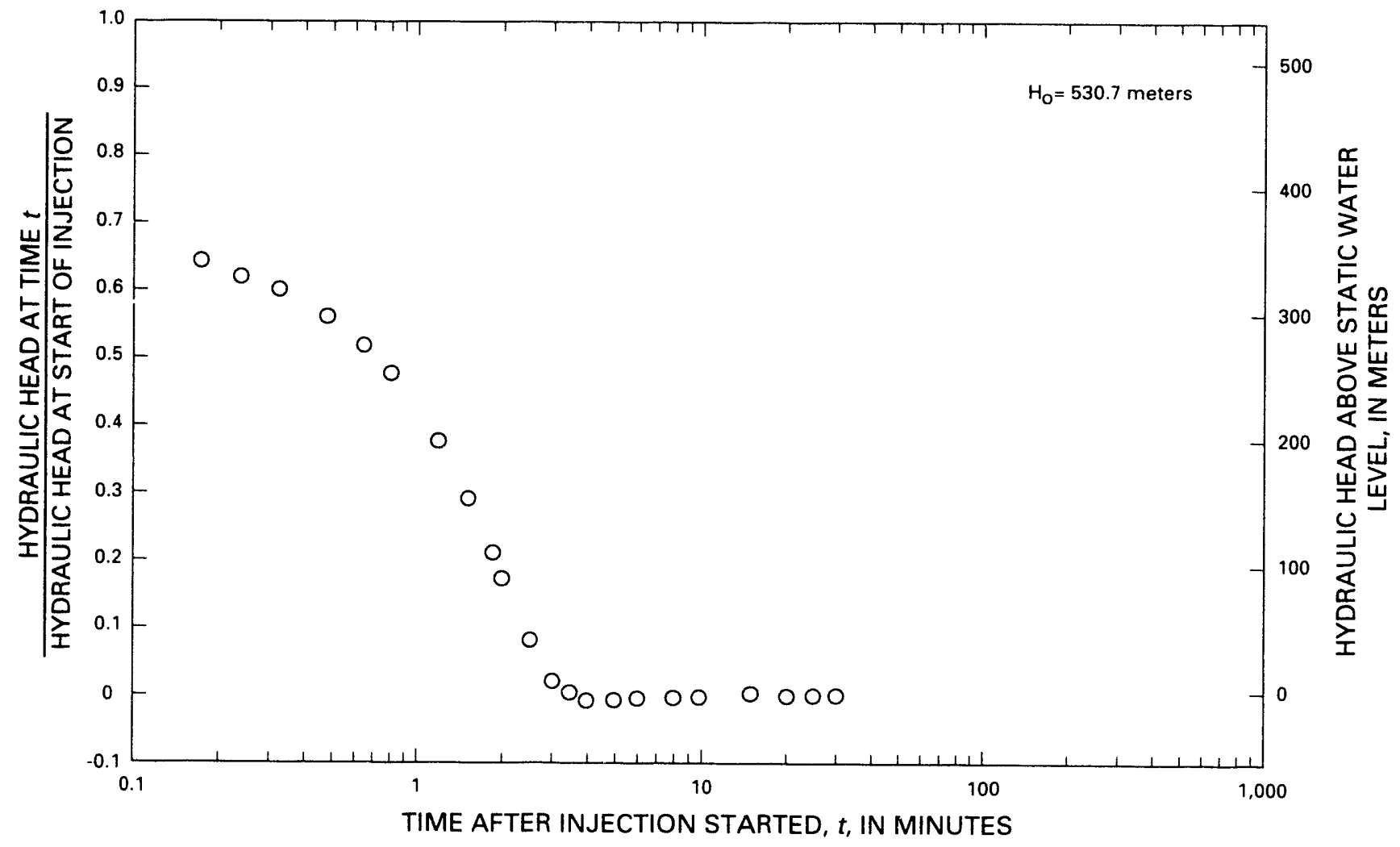

Figure 17.--Data for packer-injection test 2:

depth interval from 606 to 640 meters.

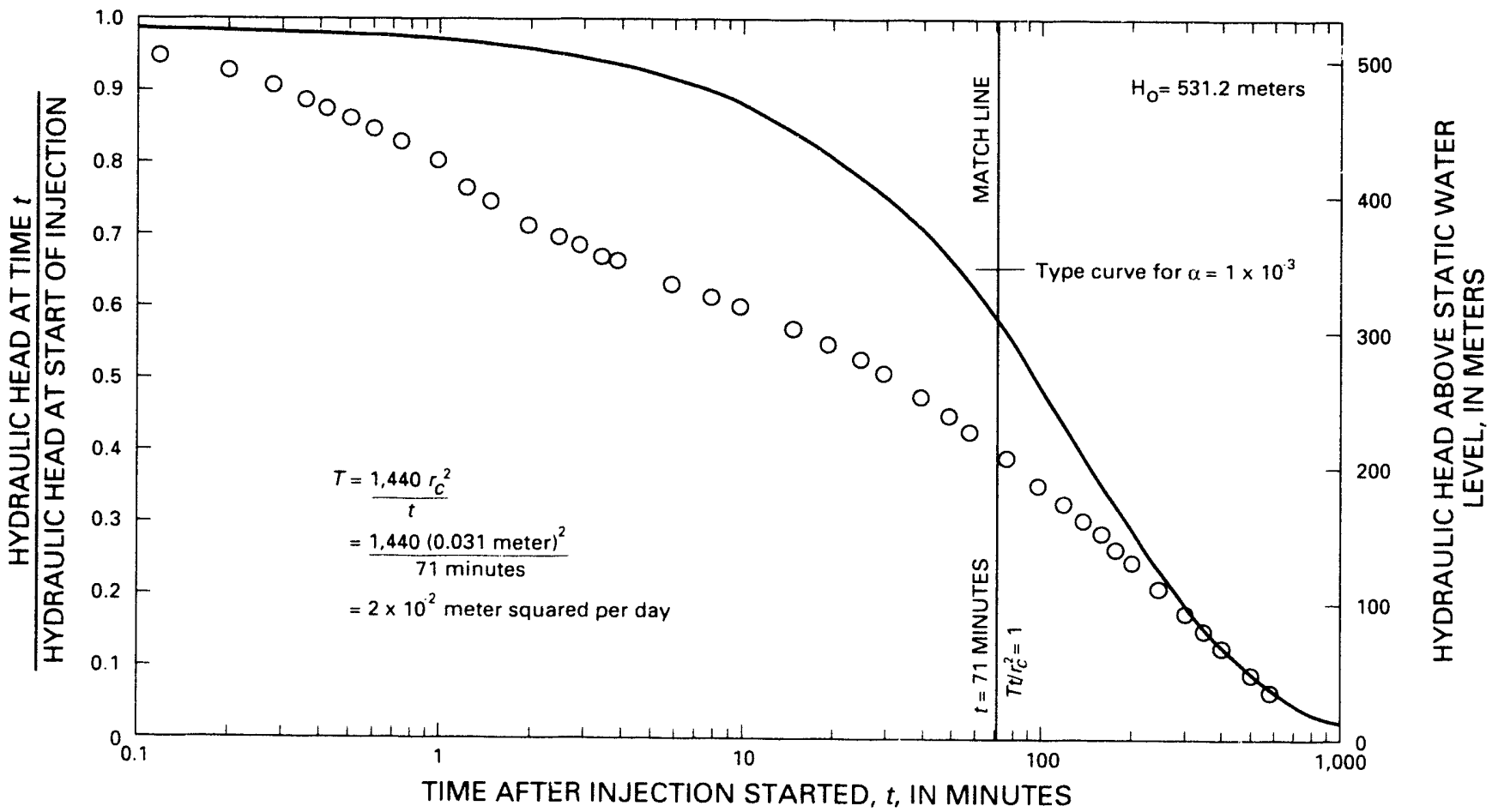

Figure 18.--Analysis of packer-injection test 3 : depth interval from 649 to 683 meters. 


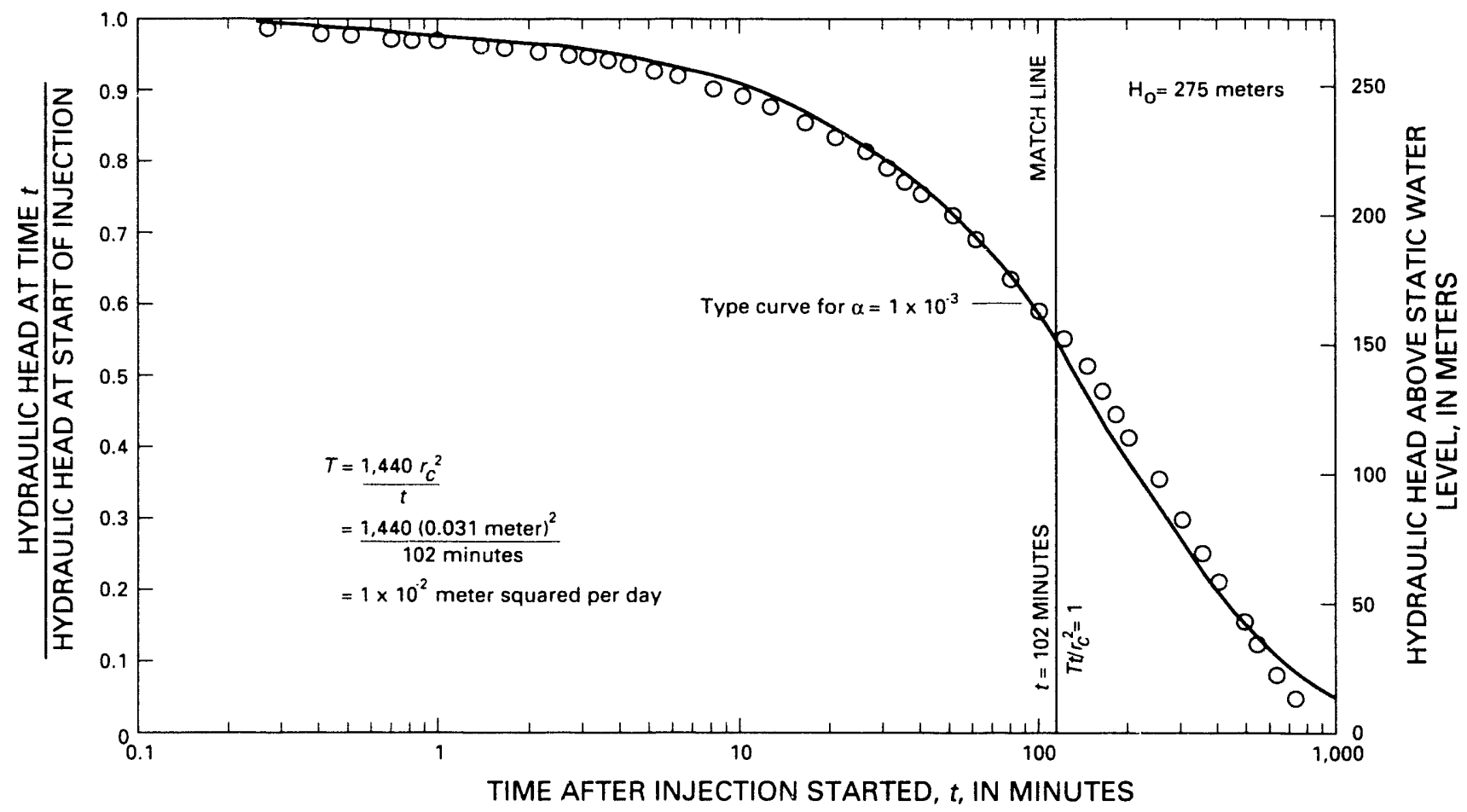

Figure 19.--Analysis of packer-injection test $3 \mathrm{~A}$ : depth interval from 649 to 683 meters.

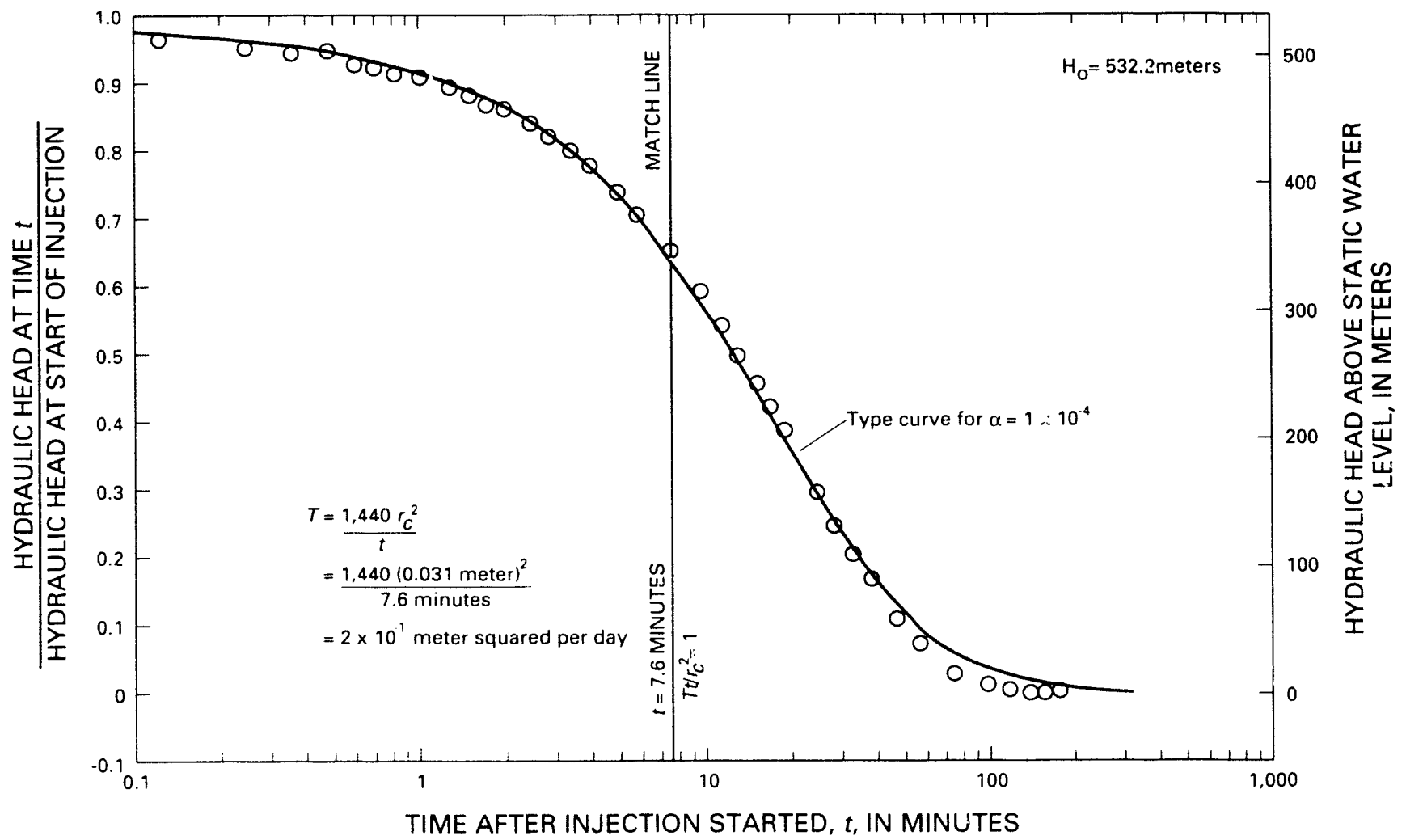

Figure 20.=-Analysis of packer-injection test 4: depth interval from 686 to 753 meters. 


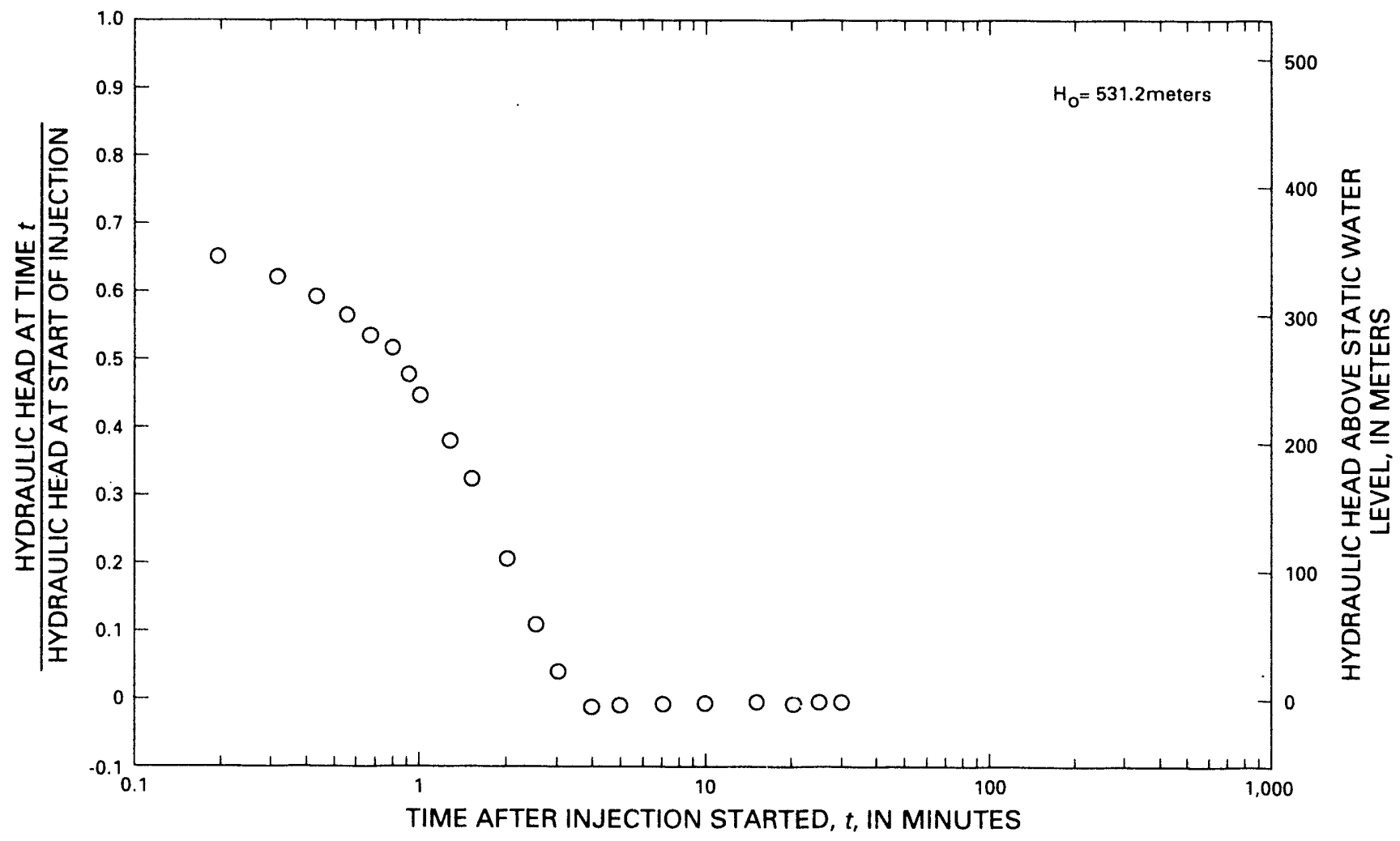

Figure 21.--Data for packer-injection test 5: depth interval from 753 to 787 meters.

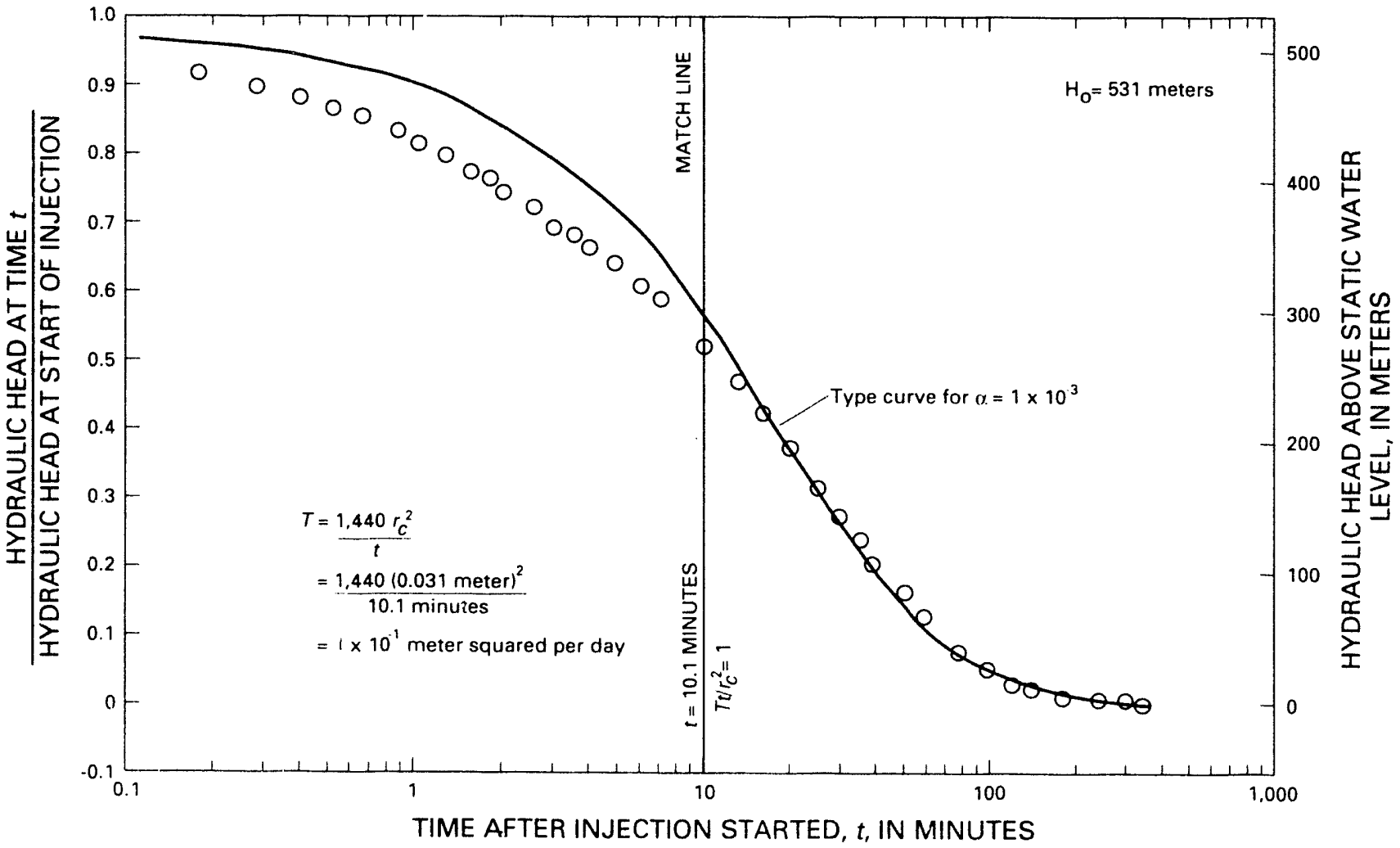

Figure 22.--Analysis of packer-injection test 6 : depth interval from 804 to 838 meters. 


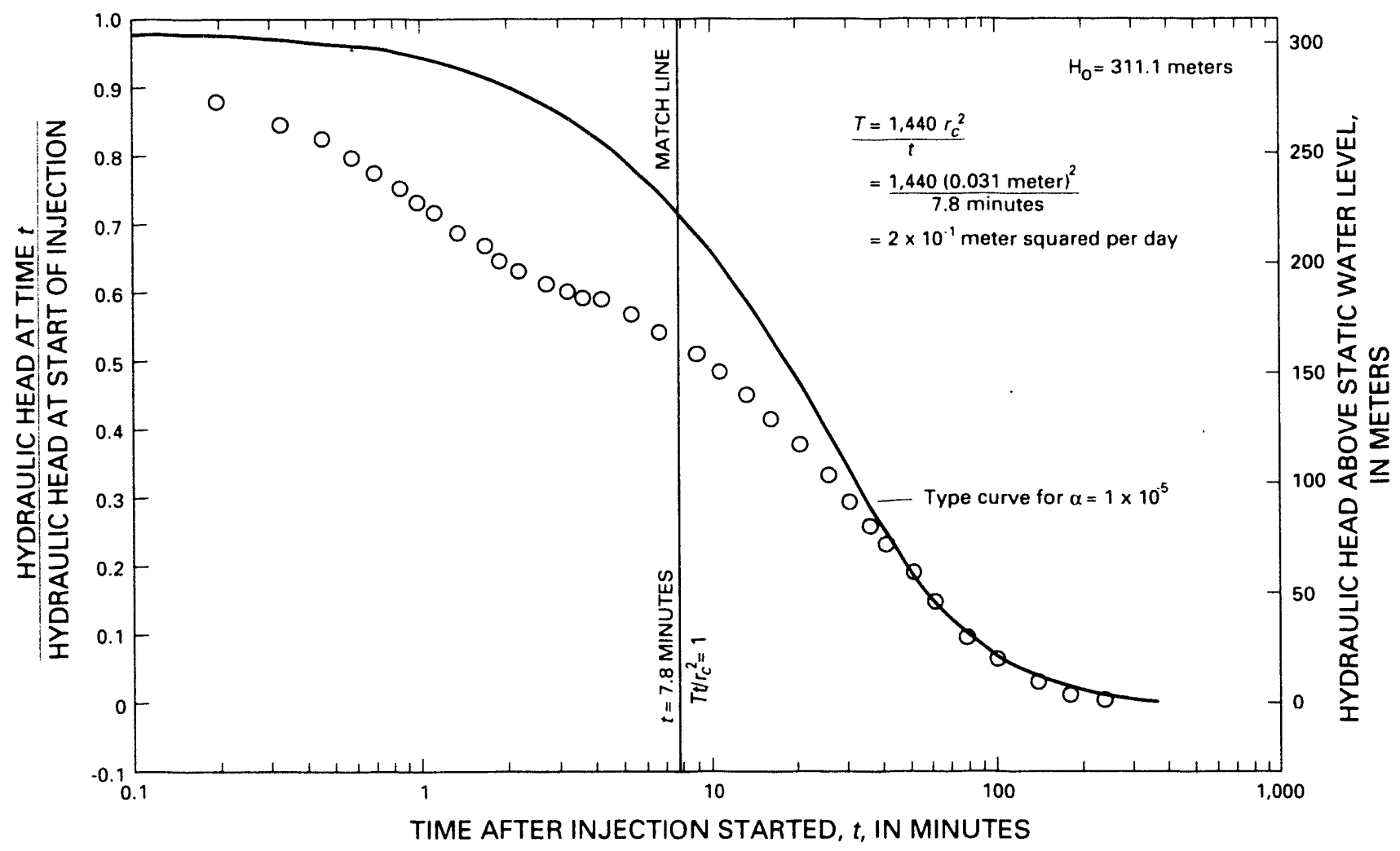

Figure 23.--Analysis of packer-injection test 7 : depth interval from 835 to 869 meters.

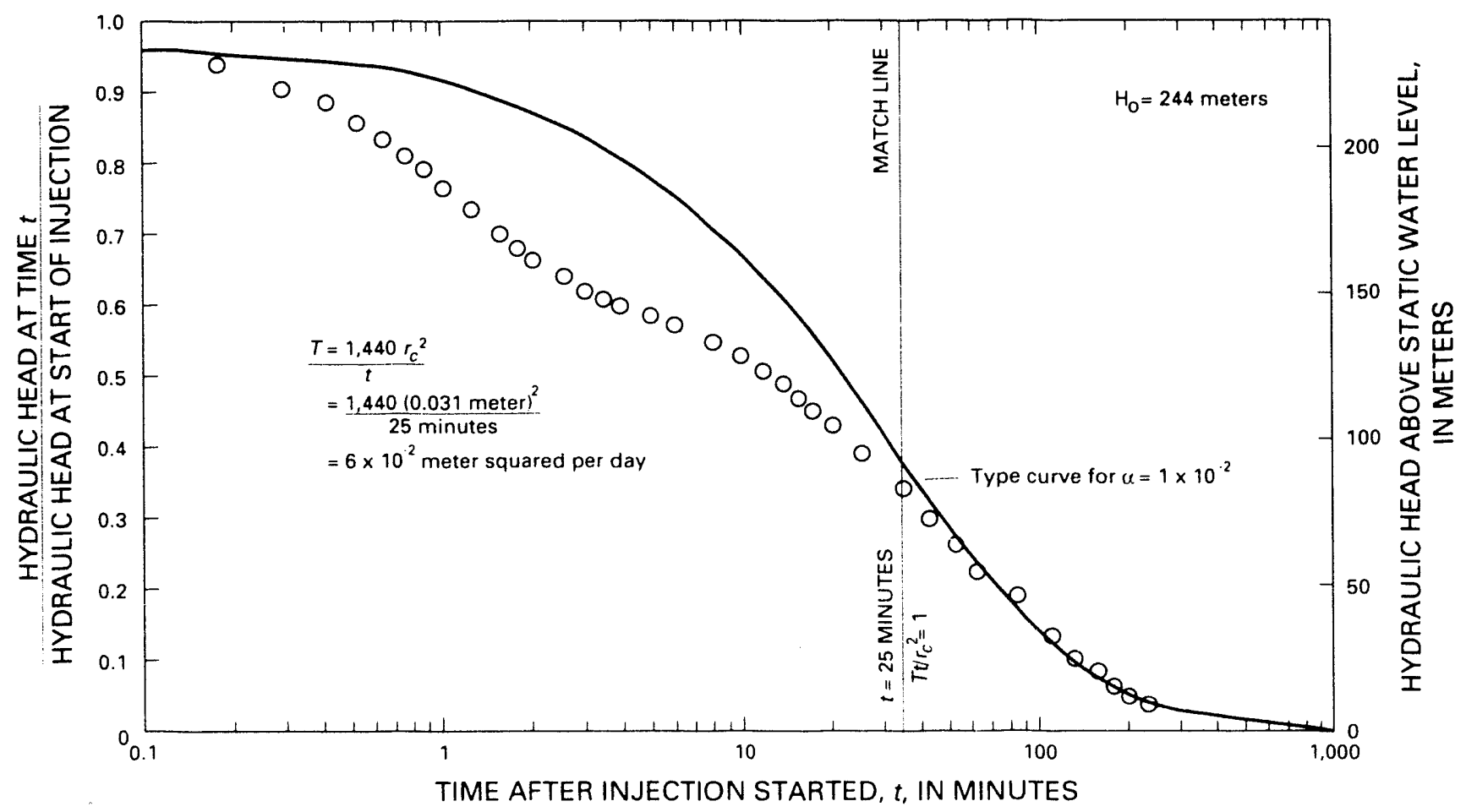

Figure 24.--Analysis of packer-injection test 8: depth interval from 871 to 1,220 meters. 


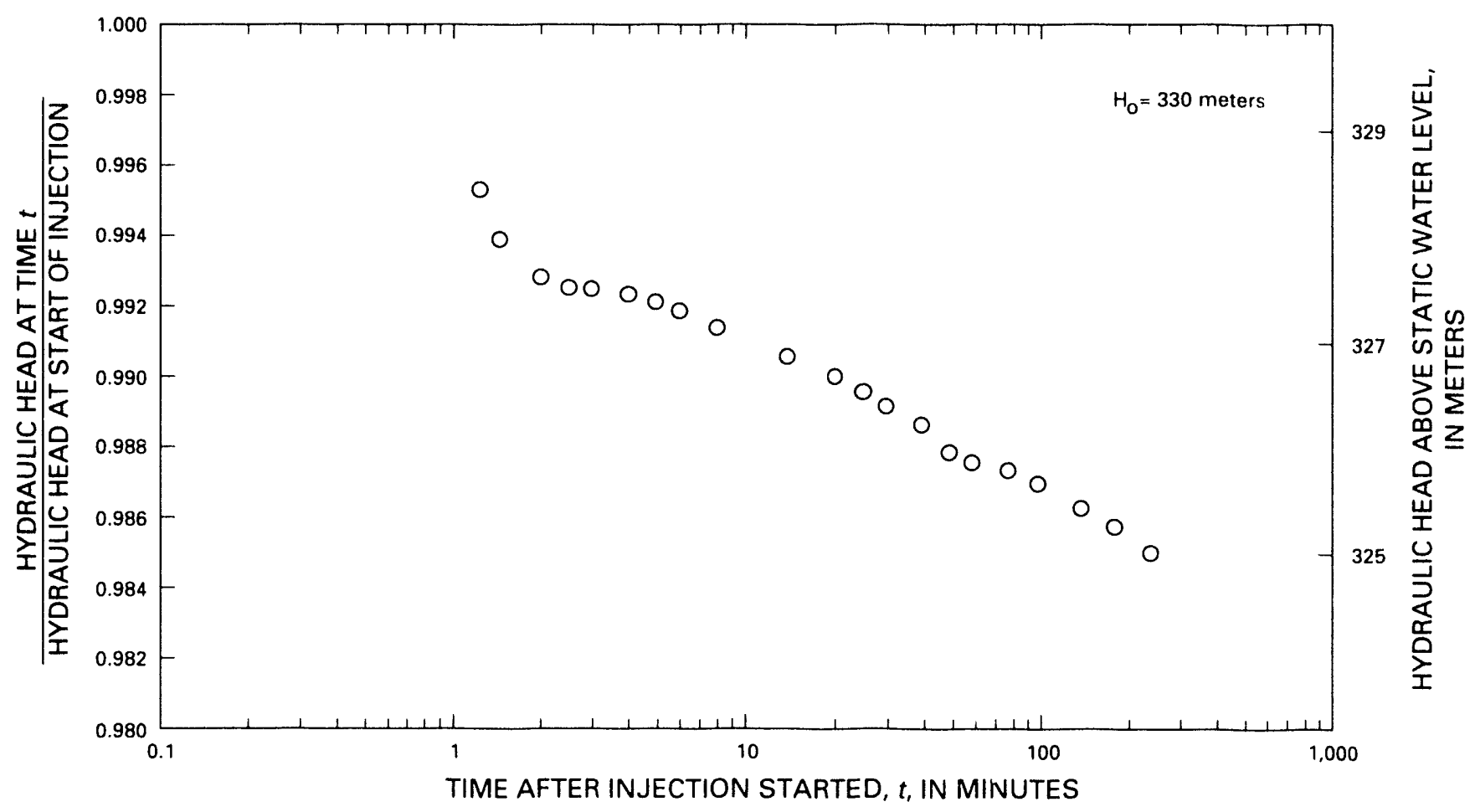

Figure 25.--Data for packer-injection test 9: depth interval from 1,118 to 1,152 meters.

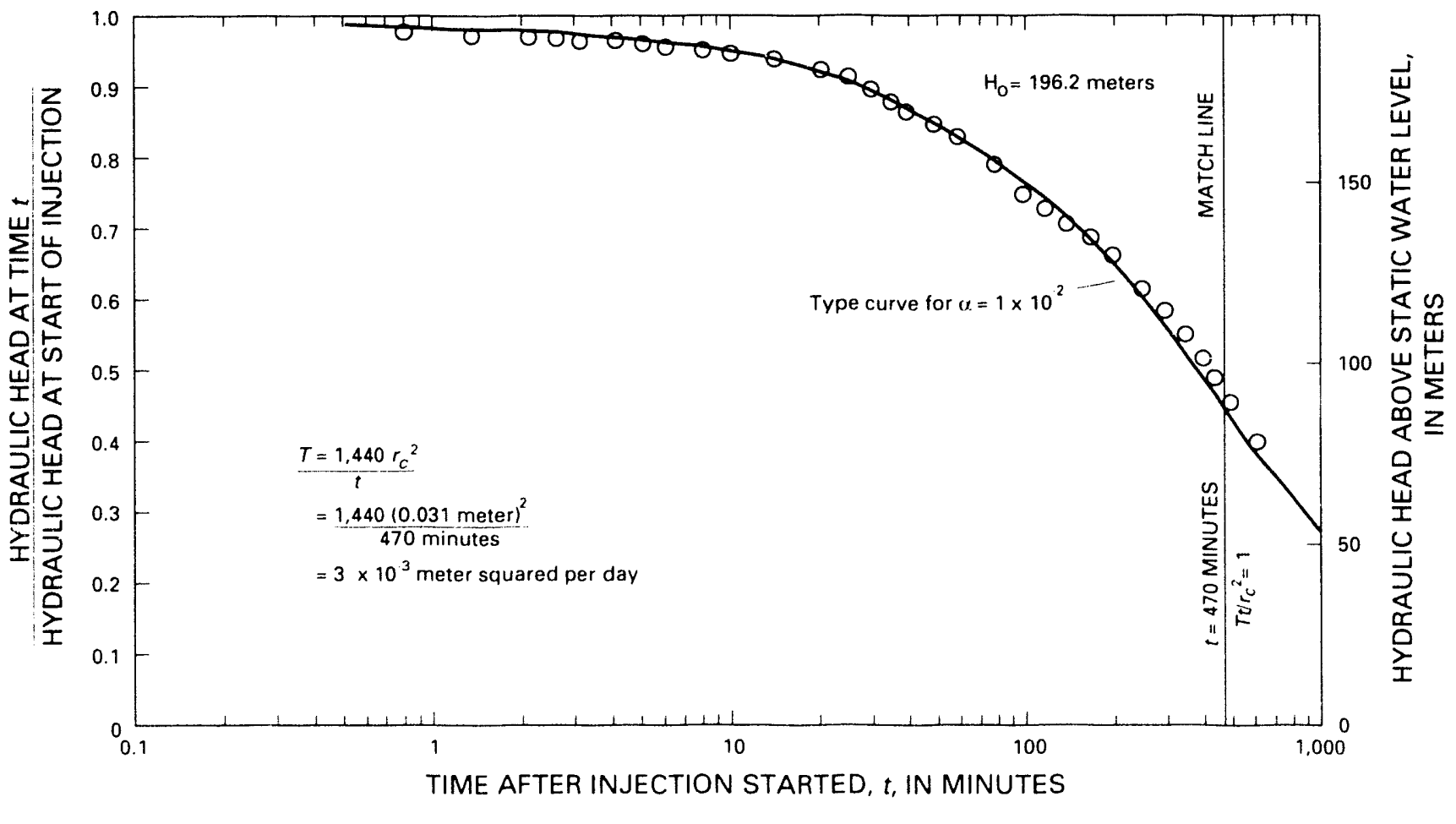

Figure 26.--Analysis of packer-injection test 10: depth interval from 1,155 to 1,220 meters. 
As Cooper and others (1967) point out, the shapes of the type curves differ only slightly when $\alpha$ differs by an order of magnitude, where $\alpha$ is the product of the storage coefficient and the ratio of the radius squared of the open hole to the radius squared of the casing in the interval within which the water level fluctuates. Shifting from one type curve to an adjoining type curve results in a change in the storage coefficient by an order of magnitude, whereas the change in calculated transmissivity is much less.

Cooper and others (1967) recommend that the storage coefficient be estimated, based on knowledge of the local hydrogeologic system, thereby providing an estimate of the $\alpha$ value and type curve to use for matching the data plot.

Calculation of transmissivity was by the following equation (Cooper and others, 1967, p. 267):

$$
T=\frac{1440 r_{c}^{2}}{t}
$$

where $T=$ transmissivity, in meters squared per day;

$r_{c}=$ radius of tubing in interval within which water level fluctuates, in meters; and

$t=$ match line of time since injection started, in minutes.

Packer-injection tests produced some anomalous results. Significant deviations from expected data curves occurred during tests 3,7 , and 8 (figs. 18, 23, and 24). These tests yielded data curves that were doublehumped. Deviations from the expected shape are attributed to a long initial water column that substantially overpressured the tested intervals.

The practice of filling the injection tubing to the top of the tubing, a few meters above land surface, has advantages: (1) The water level can be observed easily without measuring devices, to determine if packers or tubing are leaking; and (2) when the tubing is filled, it is easy to observe when the water column is degassed. However, analysis of packer-injection tests performed in test well USW H-6 indicate disadvantages of using a long water column that had not been apparent during previous testing of other wells near Yucca Mountain:

1. The water column may temporarily increase fracture apertures; this effect probably is what results in double-humped curves.

2. During tests of zones with greater relative permeability, velocities of water flowing past the pressure transducer in the injection tube may be fast enough to give erroneous readings.

3. Inertial effects may be significant during the early part of some tests. Inertial effects are not accounted for by the method of Cooper and others (1967).

Based on packer-injection tests at test well USW H-6, the following seems to be applicable for any future testing of fractured rocks with deep water levels: 
1. Use the shortest practical water column, probably on the order of tens of meters.

2. If possible, compare results of testing an interval, or intervals, with water columns of different heights, starting with the shortest water column. Possibly start as low as $10 \mathrm{~m}$ above static-water level.

Results of packer-injection tests are summarized in table 3 . Also listed in table 3 are the estimated $\alpha$ value, assuming a specific storage of $3.3 \times 10^{-6} / \mathrm{m}$, and the $\alpha$ value of the type curve used to match the data curve. During curve matching, the estimated $\alpha$ curve was used as a guide. The apparent best fit with either the estimated $\alpha$ curve or the next larger or smaller $\alpha$ curve was used in all but two tests. The estimated $\alpha$ value for test 1 was $9 \times 10^{-5}$, whereas the best fit was with the $\alpha$ curve for $1 \times 10^{-1}$; results of this test are questionable. The best match of data from test 10 with a type curve was achieved with a $\alpha$ curve two orders of magnitude greater than the estimated $\alpha$ value. The data fit to the type curve was good and probably indicates that the assumed specific storage was too small for test interval 10.

Test interval 2, in the middle part of the Bullfrog Member of the Crater Tlat Tuff, and test interval 5, in the middle part of the Tram Member of the Crater Flat Tuff, had an apparent transmissivity greater than $5 \mathrm{~m}^{2} / \mathrm{d}$. The time to reach static water level in each test was about 4 minutes. The remaining test intervals had a calculated transmissivity less than $1 \mathrm{~m}^{2} / \mathrm{d}$, with most values being about $1 \times 10^{-1} \mathrm{~m}^{2} / \mathrm{d}$ or less. The depth interval from 649 to $683 \mathrm{~m}$ was tested twice: (1) The first time (test 3 ), the tubing was filled to $531 \mathrm{~m}$ above the static water level; and (2) The second time (test $3 \mathrm{~A}$ ), the tubing was filled to $275 \mathrm{~m}$ above the static water level. Although the calculated values of transmissivity of $2 \times 10^{-2}$ and $1 \times 10^{-2}$ were in reasonable agreement for the two tests, the type-curve match for test 3 is so poor that it cannot be considered valid. Test 9 in the depth interval from 1,118 to $1,152 \mathrm{~m}$ indicated that this interval is not permeable. Testing was conducted for 240 minutes, at which time testing was stopped, with 1.5 percent of the water column dissipated. A check of pressure-gage readings in the test interval indicated that the data were valid. No numerical value of transmissivity was obtained, but the transmissivity of the interval probably is negligible.

Resuits of tests $3 \mathrm{~A}, 4,10$, and perhaps 6 are probably the closest to true values, based on the fit of data curves to type curves and reasonableness of results. The results of tests with double-humped data curves (tests 3,7 and 8 ) are questionable, as are the results of test 1 . Values of horizontal hydraulic conductivity were calculated for data that matched a type curve by dividing the computed values of transmissivity by the length of the test interval; values ranged from $1 \times 10^{-2}$ to $5 \times 10^{-5} \mathrm{~m} / \mathrm{d}$. Values of about $1 \times 10^{-2} \mathrm{~m} / \mathrm{d}$ probably reflected a component of fracture hydraulic conductivity, whereas values of about $5 \times 10^{-5} \mathrm{~m} / \mathrm{d}$ were probably representative of matrix hydraulic conductivity. 


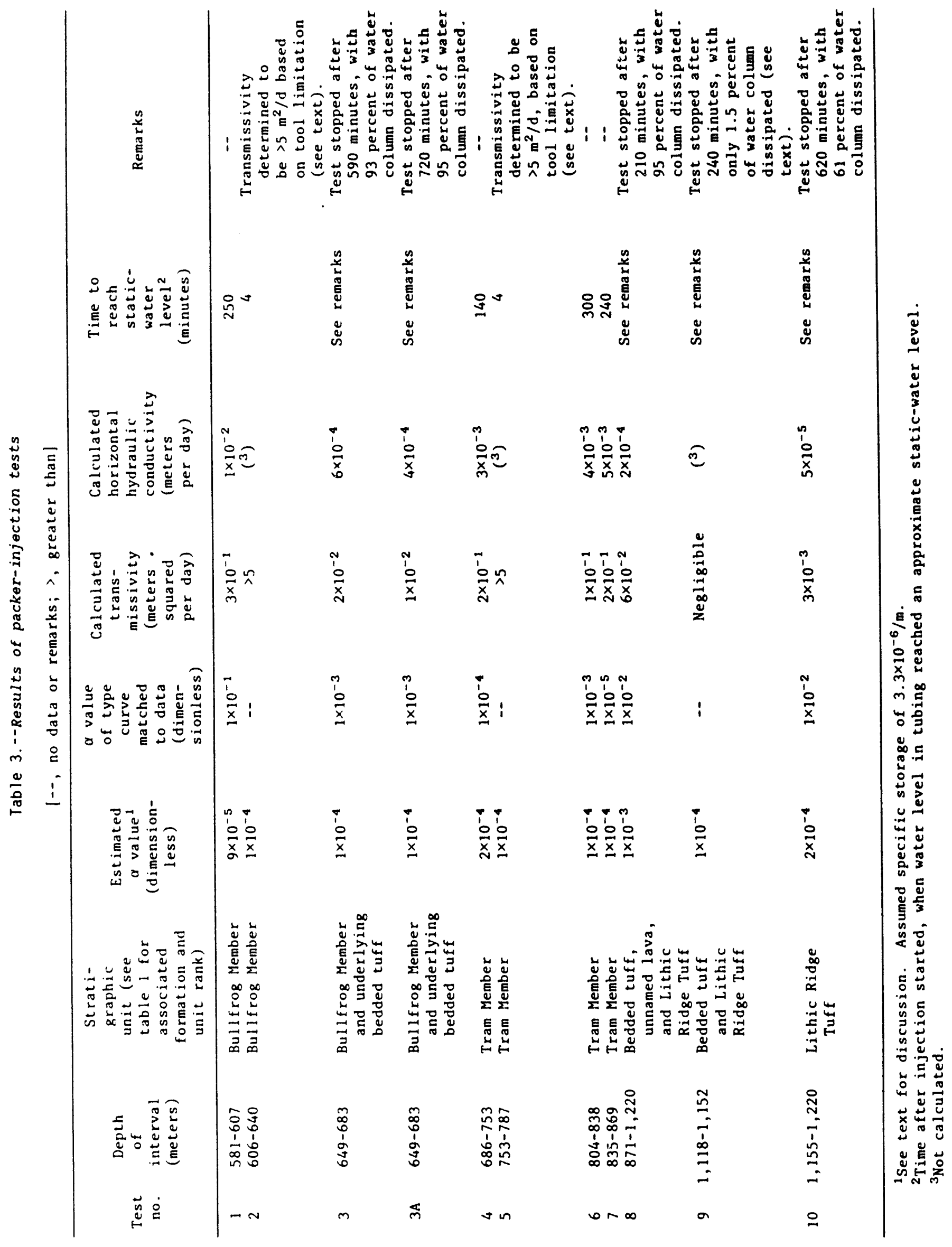


Results of the packer-injection tests were not inconsistent with results of the pumping tests and the flow survey, as summarized in table 4. Transmissivity determined from pumping tests was separated into intervals of the packer-injection tests, by percentage of production for each interval, as determined by the borehole-flow survey. In the two intervals for which the borehole-flow survey indicated primary production, injection tests indicated values of transmissivity greater than $5 \mathrm{~m}^{2} / \mathrm{d}$. In intervals for which the borehole-flow survey detected no production, calculated values of transmissivity, based on injection tests, were about $1 \times 10^{-1} \mathrm{~m}^{2} / \mathrm{d}$ or less. In the depth interval from 581 to $607 \mathrm{~m}$, a transmissivity of about $14 \mathrm{~m}^{2} / \mathrm{d}$ was calculated from results of the pumping test and the borehole-flow survey, whereas a value of $3 \times 10^{-1} \mathrm{~m}^{2} / \mathrm{d}$ was calculated from the injection-test results. Results for this interval were expected to be similar to results for tests 2 and 5 .

Table 4.--Comparison of calculated values of transmissivity determined from pumping tests and the borehole-flow survey to those determined from packer-injection tests

[>, greater than; $\sim$, about]

\begin{tabular}{|c|c|c|c|c|c|}
\hline \multirow{2}{*}{\multicolumn{2}{|c|}{$\begin{array}{l}\text { Depth interval } \\
\text { (meters) }\end{array}$}} & \multicolumn{3}{|c|}{$\begin{array}{l}\text { Transmissivity } \\
\text { (meters squared per day) }\end{array}$} & \multirow{2}{*}{$\begin{array}{l}\text { Stratigraphic unj.t } \\
\text { (see table } 1 \text { for } \\
\text { associated formation } \\
\text { and rank of unit) }\end{array}$} \\
\hline & & \multicolumn{2}{|c|}{$\begin{array}{l}\text { Pumping tests and } \\
\text { borehole-flow } \\
\text { survey }\end{array}$} & $\begin{array}{c}\text { Packer-injection } \\
\text { tests }\end{array}$ & \\
\hline $581-2$ & 607 & & 14 & $3 \times 10^{-1}$ & Bullfrog Member \\
\hline 606 & 640 & & 140 & $>5$ & Bullfrog Member \\
\hline 649 & 683 & No & flow detected & $\sim 1 \times 10^{-2}$ & $\begin{array}{l}\text { Bullfrog Member and } \\
\text { underlying bedded } \\
\text { tuff }\end{array}$ \\
\hline 686 & 753 & & flow detected & $2 \times 10^{-1}$ & Tram Member \\
\hline 753 & 787 & & 75 & $>5$ & Tram Member \\
\hline 804 & 838 & & flow detected & $1 \times 10^{-1}$ & Tram Member \\
\hline 835 & $-\quad 869$ & & flow detected & $2 \times 10^{-1}$ & Tram Member \\
\hline 871 & $-1,220$ & & flow detected & $6 \times 10^{-2}$ & $\begin{array}{l}\text { Bedded tuff, unnamed } \\
\text { lava and Lithic } \\
\text { Ridge Tuff }\end{array}$ \\
\hline
\end{tabular}

\section{GROUND-WATER CHEMISTRY}

A water sample for chemical analysis was collected near the end of pumping test 2. At time of collection, about $1.2 \times 10^{7} \mathrm{~L}$ of water had been withdrawn from the well during combined periods of pumping. Because of distribution of permeability, the sample mainly represented water from depth intervals from 616 to $631 \mathrm{~m}$, and from 777 to $788 \mathrm{~m}$. Results of the chemiral analysis are listed in table 5 . The water is a sodium bicarbonate type, which is typical of water from tuffaceous rocks of southern Nevada (Winograd and Thordarson, 1975, p. C97). Isotope-ratio determinations for oxygen-18 and oxygen-16 and for deuterium-hydrogen indicated that the ground water was derived from precipitation. Carbon- 14 determination indicated that the sample had an apparent age of about 14,600 years. 
Table 5.--Results of chemical analysis ${ }^{1}$ of water sample collected during pumping of depth interval from 526 to 1,220 meters

[All units are milligrams per liter unless otherwise indicated; date of collection, 10/16/82]

\begin{tabular}{|c|c|}
\hline $\begin{array}{l}\text { Physical properties } \\
\text { or } \\
\text { chemical constituents }\end{array}$ & $\begin{array}{l}\text { Value } \\
\text { or } \\
\text { concentration }\end{array}$ \\
\hline $\begin{array}{l}\text { Specific conductance, field (microsiemens } \\
\text { per centimeter at } 25^{\circ} \text { Celsius) } \\
\text { pH, laboratory (units) } \\
\text { pH, field (units) } \\
\text { Temperature (degrees Celsius) } \\
\text { Calcium (Ca) }\end{array}$ & $\begin{array}{r}379 \\
8.3 \\
8.1 \\
37.8 \\
4.1\end{array}$ \\
\hline $\begin{array}{l}\text { Magnesium ( } \mathrm{Mg} \text {, micrograms per liter) } \\
\text { Sodium ( } \mathrm{Na}) \\
\text { Potassium (K) } \\
\text { Bicarbonate }\left(\mathrm{HCO}_{3}\right) \text {, field } \\
\text { Sulfate }\left(\mathrm{SO}_{4}\right)\end{array}$ & $\begin{array}{c}90 \\
86 \\
1.3 \\
182 \\
29\end{array}$ \\
\hline $\begin{array}{l}\text { Chloride ( } \mathrm{Cl}) \\
\text { Fluoride }(\mathrm{F}) \\
\text { Silica }\left(\mathrm{SiO}_{2}\right) \\
\text { Residue on evaporation } \\
\text { Lithium ( } \mathrm{Li}, \text { micrograms per liter) }\end{array}$ & $\begin{array}{r}7.6 \\
4.7 \\
48 \\
263 \\
82\end{array}$ \\
\hline $\begin{array}{l}\text { Strontium ( } \mathrm{Sr} \text {, micrograms per liter) } \\
\left.\text { Oxygen-18/oxygen-16( } \delta^{18} \mathrm{O}\right)^{2} \\
\text { Deuterium/hydrogen }\left(\delta^{2} \mathrm{H}\right)^{3} \\
\text { Carbon-13/carbon-12 }\left(\delta^{13} \mathrm{C}\right)^{4} \\
\text { Carbon-14 (percent of modern standard) }\end{array}$ & $\begin{array}{l}8 \\
-13.8 \\
-106 \\
-7.5 \\
16.3\end{array}$ \\
\hline $\begin{array}{l}\text { Tritium (picocuries per liter) } \\
\text { Cations (milliequivalents per liter) } \\
\text { Anions (milliequivalents per liter) } \\
\text { Difference (percent) }\end{array}$ & $\begin{array}{l}<10 \\
3.996 \\
4.053 \\
-0.71\end{array}$ \\
\hline
\end{tabular}

${ }^{1}$ Chemical analyses made by U.S. Geological Survey laboratory, Denver, Colorado.

${ }^{2}$ Deviation of oxygen-18/oxygen-16 ratio of sample from standard mean ocean water (SMOW) relative to SMOW, in parts per thousand.

${ }^{3}$ Deviation of deuterium/hydrogen ratio of sample from standard mean ocean water (SMOW) relative to SMOW, in parts per thousand.

${ }^{4}$ Deviation of carbon-13/carbon-12 ratio of sample from Peedee belemnite standard (PDB) relative to $\mathrm{PDB}$, in parts per thousand. 
Water production in the saturated zone of test well USW H-6 was coincident with fractured, partially, and partially to moderately welded tuff units. The reverse was not necessarily true; that is, not all fractured, partially welded tuff units produced water. To define causes of these permeable zones in rocks near the well, the relation between stratigraphy, observed fractures, degree of welding, relatively porous rocks, and major water production was examined (fig. 27). Because the borehole-flow survey indicated that production was limited to the saturated zone above a depth of $803 \mathrm{~m}$, only the depth interval from 525 to $850 \mathrm{~m}$ is shown (fig. 27).

Fractures shown (fig. 27) were those observed on a television-camera 10g. Tuff units with a greater degree of welding generally had a greater number of fractures. As the degree of welding increased, urittleness also increased, and the tuff units fractured more easily under stress. Stresses were likely due to regional tectonic activity associated with the Basin and Range province, nearby volcanic activity, and cooling and compaction of ashflow units (Carr, 1974).

The general distribution of relatively porous rocks was determined by an examination of borehole-compensated density, neutron, and acoustic logs. Relatively porous rocks were defined as those having porosity greater than an approximate mean porosity for rocks penetrated in the well, as recorded by each log. Density and neutron logs indicated both matrix and fracture porosity, whereas acoustic logs responded only to matrix porosity (Asquith and Gibsion, 1982, p. 66-67). These logs were not calibrated relative to the porosity of the ash-flow tuff units, so no attempt was made to use the logs quantitatively. The relative porosity was established by selecting an approximate mean value for each log. Logs were divided into intervals that were consistent with intervals of semiuniform welding, and a percentage of rocks in each interval greater than the norm was determined. If all rocks in an interval had a porosity greater than the norm, then the percentage (see fig. 27, column 4) was 100 . Conversely, if none of the rocks in an interval had a porosity greater than the norm, then the percentage was 0 . Where it was obvious from examination of caliper logs that density and neutron logs were responding to extreme hole enlargement rather than porosity, the response was ignored. Percentages obtained from each $10 \mathrm{~g}$ were combined into one value for each interval as shown in figure 27. The values represent the sum of subjective analyses; however, they probably are representative of the distribution of the relatively porous rocks penetrated in the well.

Based on the data shown (fig. 27), it was concluded that most permeability is associated with fractures, but not all fractures are permeable. Matrix permeability is small. Porosity and permeability of these rocks generally are inversely related. Porosity is greatest near the top and bottom of ash-flow tuff units and is the least near the center. Permeability, as indicated by water production, is greatest near the center of units, where the degree of welding is greatest.

Additional indirect evidence that permeability is primarily due to fractures was indicated by values of matrix hydraulic conductivity for rocks penetrated by test well USW H-1. Values of matrix hydraulic conductivity of core samples from test well USW H-1 (about $3.3 \mathrm{~km}$ northeast of test well 


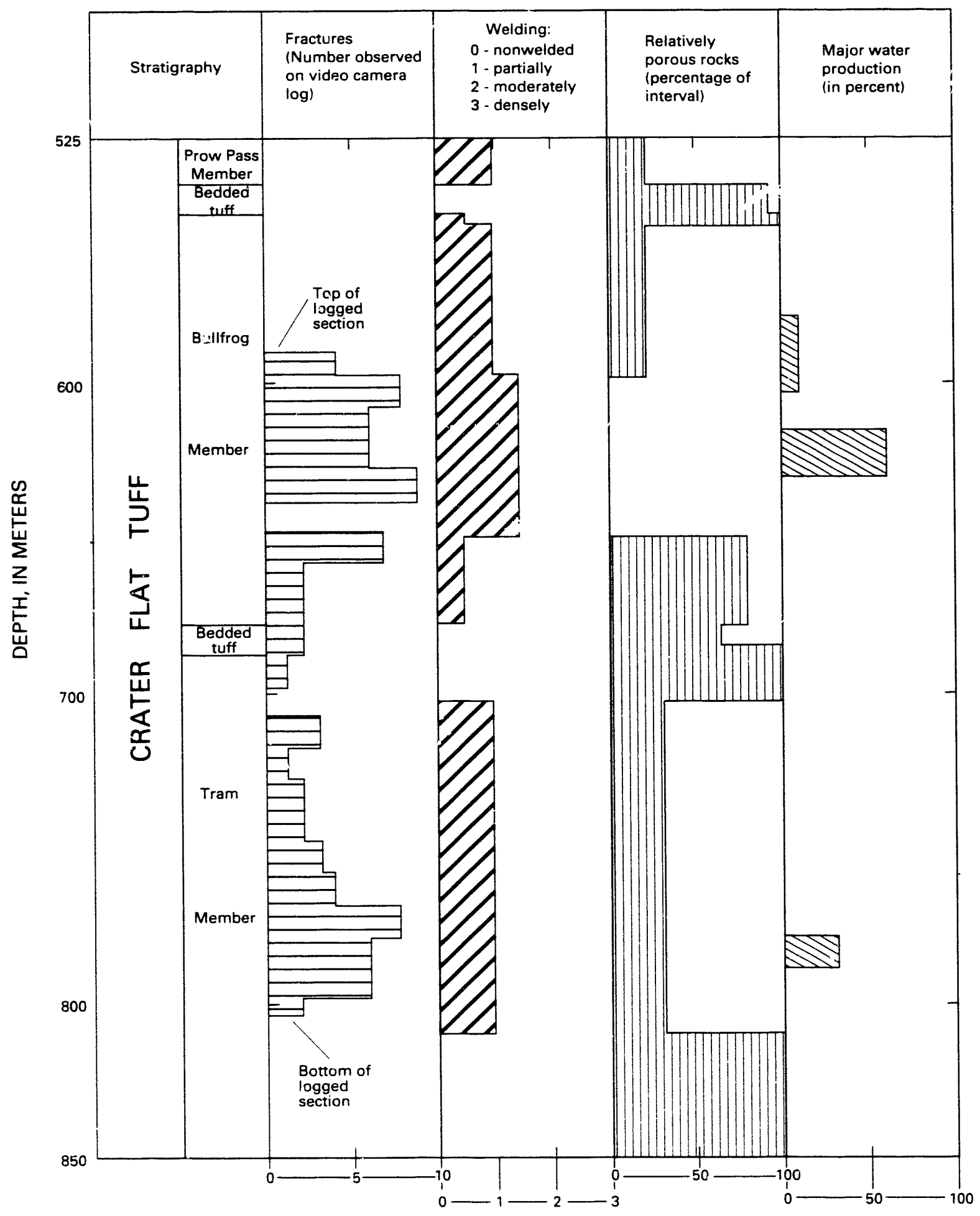

Figure 27.--Relation between stratigraphy, fractures, welding, relatively porous rocks, and major water production. 
USW H-6) were about $1 \times 10^{-4}$ to $5 \times 10^{-5} \mathrm{~m} / \mathrm{d}$ (Rush and others, 1983, p. 9). Core samples were collected from the same stratigraphic units as penetrated in test well USW H-6. In addition, packer-injection tests in test well USW H-6 confirmed the general magnitude of matrix hydraulic conductivity (see section on "Packer-Injection Tests"). Values of matrix hydraulic conductivity of the indicated magnitude could no: have supported the quantity of water produced in test well USW H-6 (see section on "Pumping and Recovery Tests, and Borehole-Flow Survey").

\section{CONCEPTUAL MODEL OF GROUND-WATER FLOW}

The accuracy of determining hydraulic characteristics of an aquifer depends to a large degree on applying the correct, or most nearly correct, model to the system under study. Porous-media models are well-known to hydrologists; systems in which heterogeneity is acknowledged are less well known. In a summary of methods for interpreting flow tests in fissured formations, Gringarten (1982, p. 237) stated that mechanisms of fluid flow in heterogeneous formations are still the subject of much debate.

The conceptual model chosen for this study is a dual-porosity model. Barenblatt and others (1960) first introduced the concept of a dual-porosity medium to represent a fractured aquifer. Later studies (Warren and Root, 1963; Odeh, 1965; Kazemi and uthers, 1969; de Swaan, 1976) investigated variations of the dual-porosity model.

The conceptual model used in this study has the following elements:

1. Both primary ald secondary porosity are present.

2. Prirary porosity is in the matrix; secondary porosity is cuntrolled by fractures.

3. Br,th primary and secondary porosity may be decreased by mineral deposition.

4. Flow to the well is through fractures only; flow occurs between the matrix and fractures. Mineral deposition (fracture skin) at the matrix-fracture surface, if present, probably decreases such flow.

5. Hydraulic conductivity of fractures is several orders of magnitude greater than hydraulic conductivity of the matrix.

6. Volume of water stored in the fractures is small relative to the volume stored in the matrix.

7. Distances between fractures are small in comparison with dimensions of the ground-water system under study.

The natural flow system is assumed to be represented by slab-shaped blocks, bounded by major water-producing fracture zones. These fracture zones are envisioned to be markedly more conductive than other interconnected fractures that may be present in the natural system. The conceptual model likely oversimplifies a complex natural system.

Data supporting the use of the conceptual model are: 
1. Production was associated with observed fractures.

2. Production was not detected in intervals without fractures.

3. Values of matrix hydraulic conductivity determined by packerinjection testing were small (about $1 \times 10^{-4} \mathrm{~m} / \mathrm{d}$, see section on "Packer-Injection Tests").

4. Pumping tests indicated that transmissivity was much larger than could be accounted for by matrix hydraulic conductivity alone (see section on "Pumping and Recovery Tests, and Borehole-Flow Survey").

The conceptual model is inconsistent with the following available information:

1. Only two major zones of water entry, spaced $150 \mathrm{~m}$ apart, exist.

2. Late-time drawdown data do not reflect typical dual-porosity characteristics.

Based $c n$ the dual-porosity model, homogeneous porous-medium solutions can be used to define general ground-water flow properties using late-time data (Odeh, 1965, p. 63; Kazemi, 1969, p. 458; Kazemi and others, 1969, p. 467; Najurieta, 1980, p. 1247; and Gringarten, 1982, p. 251). Gringarten (1982, p. 251) further stated that, at early time, water is primarily released from the fracture system, with flow from the matrix being virtually zero. At intermediate times, a transition occurs from fracture storage to a combined storage from fractures and matrix. At late time, the transition is complete and the response is like that of a homogeneous porous medium. Average values for hydraulic characteristics then can be determined for the combined system. Alternative models considered were one that assumed a homogeneous porous medium and one that assuned the presence of a recharge hydraulic boundary. A discussion of results using these models, as well as the dual-porosity model, is included in the section on "Pumping and Recovery Tests, and Borehole-Flow Survey."

The degree to which the dual-porosity model describes the actual system in the vicinity of test well USW $\mathrm{H}-6$ is not entirely known. One measure of the suitability of the model is the fit of the test data to the response predicted by the model as well as the reasonableness of the calculated properties. A good fit does not entirely rule out other models, but it does indicate that the conceptual model may adequately describe the system under study.

Pumping and recovery tests conducted in test well USW H-6 were evaluated in terms of the conceptual model, and the following elements deriving from that model:

1. A semilogarithmic data plot should show a straight-line segment in both early and late time. Transition- or intermediate-time data also should plot on a straight line of less slope. The existence of a straight line on any segment of the data plot depends on whether sufficient time had elapsed for the straight line to manifest itself. If "fracture skin" is present, the transitiontime data may develop a slope that is less than one-half that of the late-time slope, resulting in a response that is similar to that of a water-table aquifer. 
2. The previous element is dependent on late time having been reached and early-time data not having been distorted by factors such as wellbore skin effect and well storage.

According to the conceptual model, if a pumping test does not reach late time, a semilogarithmic plot will have (at most) only two straight-line segments. A similar type of drawdown-time response also could be the result of a hydraulic boundary with increased transmissivity that would appear the same as the response during the transition period of a dual-porosity model.

\section{SUMMARY AND CONCLUSIONS}

Rocks penetrated by test well USW H-6 below $9 \mathrm{~m}$ of alluvium were primarily ash-flow tuff with interspersed bedded tuff, both of Tertiary age. The lone exception was dacitic(?) lava in the depth interval from 877 to $1,126 \mathrm{~m}$. The bedded tuffs are nonwelded; the ash-flow tuffs vary from nonwelded to densely welded.

The top of the saturated zone in test well USW H-6 is at a depth of $526 \mathrm{~m}$ (776 $\mathrm{m}$ above sea level) in the Prow Pass Member of the Crater Flat Tuff. The hydraulic head of the bottom $33 \mathrm{~m}$ of the well is about $2 \mathrm{~m}$ higher than composite head for the remainder of the well.

A borehole-flow survey indicated that major water production is restricted to two zones in Crater Flat Tuff. The depth interval from 616 to $631 \mathrm{~m}$ in the Bullfrog Member yielded 60 percent of production while pumping, and the depth interval from 777 to $788 \mathrm{~m}$ in the Tram Member yielded 32 percent of production. The remaining production was above a depth of $616 \mathrm{~m}$. Based on the borehole-flow survey, it was concluded that no producing fractures occur in the depth intervals from 631 to $777 \mathrm{~m}$, and from 803 to $1,220 \mathrm{~m}$.

From analysis of two pumping tests based on the transitional part of a dual-porosity solution, calculated transmissivity is about $240 \mathrm{~m}^{2} / \mathrm{d}$. However, a large degree of uncertainty is associated with this solution. Analysis of two additional pumping tests of isolated intervals generally confirmed previous test results. Maximum estimated transmissivity probably is about $480 \mathrm{~m}^{2} / \mathrm{d}$, based on a recharge-boundary model.

Packer-injection tests indicated two intervals with apparent values of transmissivity greater than about $5 \mathrm{~m}^{2} / \mathrm{d}$. These intervals corresponded to intervals of primary production detected during the borehole-flow survey. Calculated values of apparent transmissivity for the remaining intervals ranged from $3 \times 10^{-3}$ to $3 \times 10^{-1} \mathrm{~m}^{2} / \mathrm{d}$, with one interval having a transmissivity value too small to be determined by the testing method used. Values of hydraulic conductivity for intervals with no detected fracture flow ranged from about $1 \times 10^{-3}$ to $1 \times 10^{-5} \mathrm{~m} / \mathrm{d}$; these values probably are representative of matrix hydraulic conductivity near the borehole. 


\section{REFERENCES CITED}

Asquith, G.B., and Gibson, C.R., 1982, Basic well log analysis for geologists: American Association of Petroleum Geologists, Methods in Exploration Series, 216 p. (NNA.901106.0141)

Barenblatt, G.I., Zheltov, I.P., and Kochina, I.N., 1960, Basic concepts in the theory of seepage of homogeneous liquids in fissured rocks: Journal of Applied Mathematics and Mechanics (USSR), v. 24, no. 5, p. 1286-1303. (HQS.880517.2608)

Bentley, C.B., 1984, Geohydrologic data for test well USW G-4, Yucca Mountain area, Nye County, Nevada: U.S. Geological Survey Open-File Report 84-063, 48 p. (NNA.870517.0100)

Blankennagel, R.K., 1967, Hydraulic testing techniques of deep drill holes at Pahute Mesa, Nevada Test Site: U.S. Geological Survey Open-File Report $67-18,50$ p. (NNA.870729.0095)

Bredehoeft, J.D., Cooper, H.H., Jr., and Papadopulos, I.S., 1966, Inertial and storage effects in well-aquifer systems--An analog investigation: Water Resources Research, v. 2, no. 4, p. 697-707. (NNA.901106.0143)

Byers, F.M., Jr., Carr, W.J., Orkild, P.P., Quinlivan, W.D., and Sargent, K.A., 1976, Volcanic suites and related cauldrons of Timber MountainOasis Valley caldera complex, southern Nevada: U.S. Geological Survey Professional Paper 919, 70 p. (NNA.870406.0239)

Carr, W.J., 1974, Summary of tectonic and structural evidence for stress orientation at the Nevada Test Site: U.S. Geological Survey Open-File Report 74-176, 53 p. (HQS.880517.1621)

Cooper, H.H., Jr., Bredehoeft, J.D., and Papadopulos, S.S., 1967, Response of a finite-diameter well to an instantaneous charge of water: Water Resources Research, v. 3, no. 1, p. 263-269. (HQS.880517.2643)

Cooper, H.H., Jr., and Jacob, C.E., 1946, A generalized graphical method for evaluating formation constants and summarizing well-field history: American Geophysical Union Transactions, v. 27, no. 4, p. 526-534. (NNA.891220.1666)

Craig, R.W., and Johnson, K.A., 1984, Geohydrologic data for test well UE-25p非1, Yucca Mountain area, Nye County, Nevada: U.S. Geological Survey Open-File Report 84-450,63 p. (NNA.870406.0256)

Craig, R.W., Reed, R.L., and Spengler, R.W., 1983, Geohydrologic data for test well USW H-6 Yucca Mountain area, Nye County, Nevada: U.S. Geological Survey Open-File Report 83-856, 35 p. (NNA.870406.0058)

de Swaan, A., 1976, Analytical solution for determining naturally fractured reservoir properties by well testing: Society of Petroleum Engineers Journal, v. 16, no. 3, p. 117-122. (NNA.900827.0215)

Ferris, J.G., Knowles, D.B., Brown, R.H., and Stallman, R.W., 1962, Theory of aquifer tests: U.S. Geological Survey Water-Supply Paper 1536-E, 69-174 p. (NNA.901106.0145)

Gringarten, A.C., 1982, Flow-test evaluation of fractured reservoirs, in Narasimhan, T. N., ed., Recent trends in hydrology: Geological Society of America Special Paper 189, p. 237-263. (NNA.870729.0096)

Kazemi, H., 1969, Pressure transient analysis of naturally fractured reservoirs with uniform fracture distribution: Society of Petroleum Engineers Journal, v. 9, no. 4, p. 451-462. (NNA.901106.0147)

Kazemi, H., Seth, M.S., and Thomas, G.W., 1969, The interpretation of interference tests in naturally fractured reservoirs with uniform fracture distribution: Society of Petroleum Engineers Journal, v. 9, no. 4, p. 463-472. (NNA.901106.0149) 
Lipman, P.W., and McKay, E.J., 1965, Geologic map of the Topopah Springs SW quadrangle, Nye County, Nevada: U.S. Geological Survey Geologic Quadrangle Map GQ-439, scale 1:24,000. (HQS.880517.1317)

Lobmeyer, D.H., Whitfield, M.S., Jr., Lahoud, R.R., and Bruckheimer, Laura, 1983, Geohydrologic data for test well UE-25b非1, Nevada Test Site, Nye County Nevada: U.S. Geological Survey Open-File Report 83-855, 48 p. (NNA.870406.0060)

Moench, A.E., 1984, Double-porosity models for a fissured groundwater reservoir with fracture skin: Water Resources Research, v. 20, no. 7, p. 831-846. (HQS.880517.2762)

Najurieta, H.L., 1980, A theory for pressure transient analysis in naturally fractured reservoirs: Journal of Petroleum Technology, July 1980, p. 1241-1250. (NNA.900917.0138)

Odeh, A.S., 1965, Unsteady-state behavior of naturally fractured reservoirs: Society of Petroleum Engineers Journal, v. 5, no. 1, p. 60-66. (NNA.891106.0213)

Papadopulos, S.S., Bredehoeft, J.D., and Cooper, H.H., Jr., 1973, On the analysis of "slug test" data: Water Resources Research, v. 9, no. 4, p. 1087-1089. (NNA.891220.0171)

Quiring, R.F., 1965, Annual precipitation amount as a function of elevation in Nevada south of $38 \frac{1}{2}$ degrees latitude: U.S. Weather Bureau of Research Statistics, 14 p. (NNA.870406.0428)

Robison, J.H., 1984, Ground-water level data and preliminary potentiometricsurface maps, Yucca Mountain and vicinity, Nye County, Nevada: U.S. Geological Survey Water-Resources Investigations Report 84-4197, 8 p. (NNA.870519.0096)

Rush, F.E., 1970, Regional ground-water systems in the Nevada Test Site area, Nye, Lincoln, and Clark Counties, Nevada: U.S. Geological Survey Water Resources-Reconnaissance Series Report 54, 25 p. (HQS.880517.1834)

Rush, F.E., Thordarson, William, and Bruckheimer, Laura, 1983, Geohydrologic and dril1-hole data for test well USW H-1, adjacent to Nevada Test Site, Nye County, Nevada: U.S. Geological Survey Open-File Report 83-141, 37 p. (NNA.870519.0103)

Waddell, R.K., 1982, Two-dimensional, steady-state model of ground-water flow, Nevada Test Site and vicinity, Nevada-California: U.S. Geological Survey Water-Resources Investigations Report 82-4085, 72 p. (NNA.870518.0055)

Warren, J.E., and Root, P.J., 1963, The behavior of naturally fractured reservoirs: Society of Petroleum Engineers Journal, v. 3, no. 3, p. 245-255. (NNA.890522.0726)

Winograd, I.J., and Thordarson, William, 1975, Hydrogeologic and hydrochemical framework, south-central Great Basin, Nevada-California, with a special reference to the Nevada Test Site: U.S. Geological Survey Professional Paper 712-C, 126 p. (HQS.880517.2908)

NOTE: Parenthesized numbers following each cited reference are for U.S. Department of Energy OCRWM Records Management purposes only and should not be used when ordering the publication. 

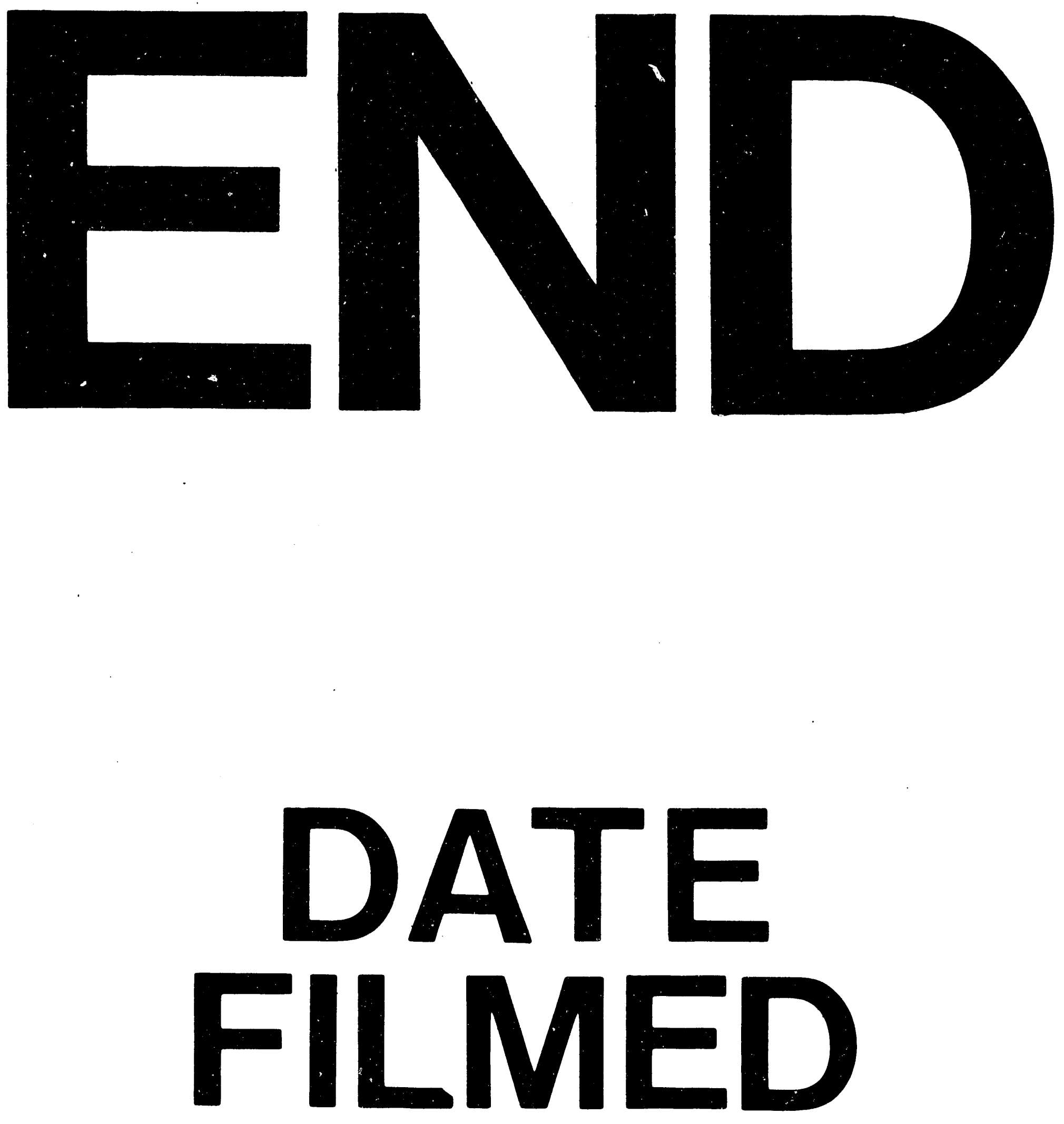

1

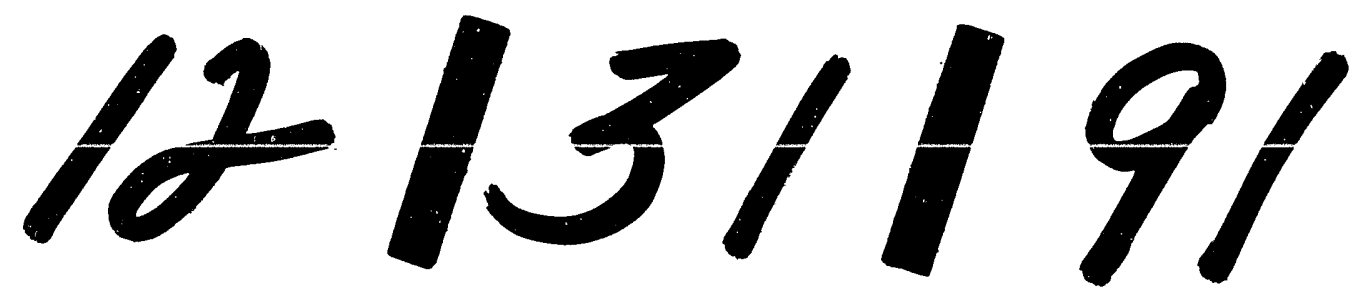


